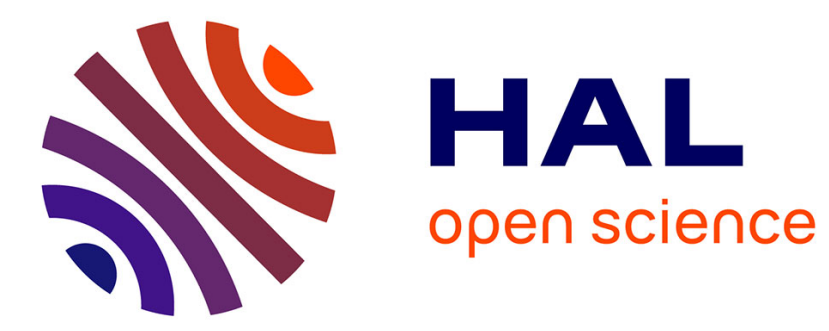

\title{
Competitive kinetics study of sulfide oxidation by chlorine using sulfite as reference compound
}

Mohamed Azizi, Pierre-François Biard, Annabelle Couvert, Mohamed Benamor

\section{- To cite this version:}

Mohamed Azizi, Pierre-François Biard, Annabelle Couvert, Mohamed Benamor. Competitive kinetics study of sulfide oxidation by chlorine using sulfite as reference compound. Chemical Engineering Research and Design, 2015, 94, pp.141-152. 10.1016/j.cherd.2014.07.023 . hal-01064049

\author{
HAL Id: hal-01064049 \\ https://hal.science/hal-01064049
}

Submitted on 8 Oct 2014

HAL is a multi-disciplinary open access archive for the deposit and dissemination of scientific research documents, whether they are published or not. The documents may come from teaching and research institutions in France or abroad, or from public or private research centers.
L'archive ouverte pluridisciplinaire HAL, est destinée au dépôt et à la diffusion de documents scientifiques de niveau recherche, publiés ou non, émanant des établissements d'enseignement et de recherche français ou étrangers, des laboratoires publics ou privés. 
3

6

7

\section{Competitive kinetics study of sulfide oxidation by chlorine using sulfite}

as reference compound

\section{Mohamed Azizi ${ }^{a, b, c}$, Pierre-François Biard ${ }^{a, b *}$, Annabelle Couvert $^{a, b}$, Mohamed Ben}

Amor ${ }^{c}$

6

${ }^{a}$ École Nationale Supérieure de Chimie de Rennes, CNRS, UMR 6226, 11 allée de Beaulieu, CS 50837, 35708 Rennes Cedex 7, France

${ }^{\mathrm{b}}$ Université européenne de Bretagne 'Laboratoire de Traitement des Eaux Naturelles, Centre des Recherches et Technologies des eaux, BP 273 Soliman 8020, Tunisie Graphical abstract

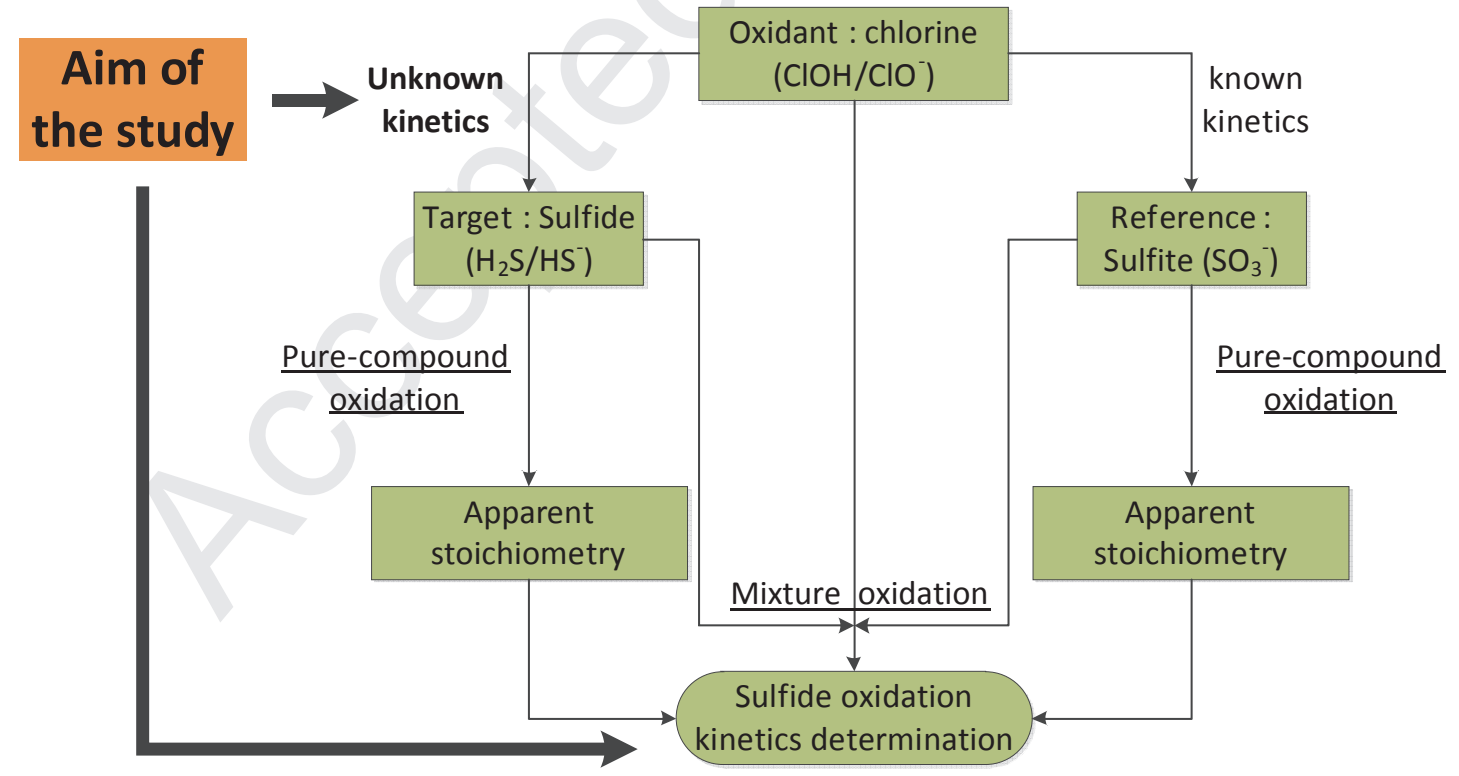

* Corresponding author: Tel: +33223238157

E-mail address: pierre-francois.biard@ensc-rennes.fr

$$
-1 / 1-
$$




\section{Abstract}

To design and optimize hydrogen sulfide scrubbers working with chlorine, the knowledge of the kinetics of the hydrogen sulfide oxidation is necessary. In this work, the kinetics of the hydrogen sulfide oxidation by sodium hypochlorite was experimentally investigated using a reactor without headspace (100 mL gas-tight syringe) and the competitive kinetics method. The sulfite ion was selected as the reference compound. First, the apparent stoichiometries of sulfite anion and hydrogen sulfide chlorinations were determined performing single-compound experiments. Then, the kinetics of the hydrogen sulfide chlorination was studied in the $\mathrm{pH}$ range 6-12 performing simultaneous sulfite and sulfide chlorinations. The results demonstrated that sulfide and sulfite oxidation kinetic rates have the same order of magnitude, which validates the choice of the sulfite anion as the reference compound. Kinetic simulations emphasized that the kinetic rates of the oxidation of both compounds were limited by acid base reactions. The sulfide oxidation in the $\mathrm{pH}$ range $6-12$ is mainly due to the hydrosulfide (HS-) oxidation by the hypochlorous acid $(\mathrm{ClOH})$ with an associated kinetic constant of $1.2 \times 10^{9} \mathrm{~L} \mathrm{~mol}^{-1} \mathrm{~s}^{-1}$ at $25^{\circ} \mathrm{C}$. 


\section{INTRODUCTION} Hydrogen sulfide $\left(\mathrm{H}_{2} \mathrm{~S}\right)$ is a toxic compound involved in emissions from many

industries such as waste water treatment or pulp industry (Gostelow et al., 2001; Kangas et al., 1984; Rappert and Müller, 2005). Several processes are currently used to remove $\mathrm{H}_{2} \mathrm{~S}$ : biofiltration, absorption in chlorine solution, absorption in alkanolamine solutions, absorption using the Claus process or catalysts to recover elemental sulfur, etc. (Busca and Chiara, 2003; Kohl and Nielsen, 1997).

Chemical scrubbing, which provides high and reliable efficiencies, is widely used for hydrogen sulfide removal. The process involves mass transfer in an aqueous solution using a gas-liquid contactor. At acid $\mathrm{pH}, \mathrm{H}_{2} \mathrm{~S}$ is poorly soluble in water. However, hydrogen sulfide apparent solubility increases with the $\mathrm{pH}$. Indeed, $\mathrm{H}_{2} \mathrm{~S}$ is a weak diacid which dissociates into hydrosulfide (or bisulfide) $\mathrm{HS}^{-}\left(\mathrm{pK}_{\mathrm{a}, 1}=7.0\right.$ at $25^{\circ} \mathrm{C}$ ) and sulfide anions as showed by Eqs (1) and (2) (Roustan, 2003):

$\mathrm{H}_{2} \mathrm{~S}+\mathrm{H}_{2} \mathrm{O} \underset{\mathrm{k}_{-1}}{\stackrel{\mathrm{k}_{1}}{\rightleftarrows}} \mathrm{HS}^{-}+\mathrm{H}_{3} \mathrm{O}^{+} \quad \mathrm{K}_{\mathrm{a}, 1}=\mathrm{k}_{1} / \mathrm{k}_{-1}$

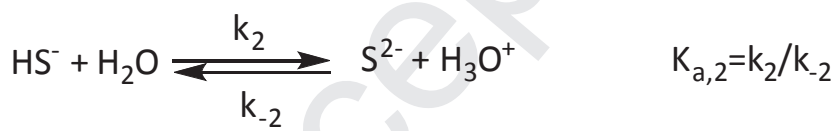

Authors' results diverge about the value of $\mathrm{pK}_{a, 2}$, reported from 12 to 17 (Giggenbach, 1971; Licht et al., 1990; Meyer et al., 1983; Migdisov et al., 2002; Stephens and Cobble, 1971). However, the most recent articles are all concordant and confirm a value around 17. Consequently, $\mathrm{S}^{2-}$ can be neglected in most aqueous media. Oxidants are often added to regenerate the scrubbing solution and to enhance mass transfer. The most frequently oxidants used are chlorine (Biard et al., 2010; Biard et al., 2009; Bonnin, 1991; Cadena and 
Peter, 1988; Chen et al., 2001), ozone (Kerc and Olmez, 2010) and hydrogen peroxide (Couvert et al., 2006; Féliers et al., 2001).

Proving an excellent efficiency at rather low cost, chlorine is widely used for $\mathrm{H}_{2} \mathrm{~S}$ chemical scrubbing. Chlorine has attracted significant commercial attention for its wide scope in the fields of bleaching, oxidation, and disinfection. Gaseous chlorine $\left(\mathrm{Cl}_{2}\right)$ or sodium hypochlorite $(\mathrm{NaOCl})$ are commonly used for chlorination processes (Deborde and Von Gunten, 2008). Due to the complex chlorine chemistry in water, various species may be present in the solution. Indeed, chlorine gas is hydrolyzed into hypochlorous acid $(\mathrm{ClOH})$ according to the following reaction (Eq. 3):

$$
\mathrm{Cl}_{2}+\mathrm{H}_{2} \mathrm{O} \underset{\mathrm{k}_{-3}}{\stackrel{\mathrm{k}_{3}}{\rightleftarrows}} \mathrm{ClOH}+\mathrm{Cl}^{-}+\mathrm{H}^{+} \quad \mathrm{K}_{3}=\mathrm{k}_{3} / \mathrm{k}_{-3}
$$

Wang and Margerum (1994) demonstrated that $\mathrm{K}_{3}$ is equal to $5.110^{-4} \mathrm{~L}^{2} \mathrm{~mol}^{-2}$ at $25^{\circ} \mathrm{C}$ and for a negligible ionic strength (Wang and Margerum, 1994). Hypochlorous acid is a weak acid which dissociates in turn into hypochlorite anions (Eq. 4):

$$
\mathrm{ClOH}+\mathrm{H}_{2} \mathrm{O} \underset{\mathrm{k}_{-4}}{\stackrel{\mathrm{k}_{4}}{\rightleftarrows}} \mathrm{ClO}^{-}+\mathrm{H}_{3} \mathrm{O}^{+} \quad \mathrm{K}_{\mathrm{a}, 4}=\mathrm{k}_{4} / \mathrm{k}_{-4}=\mathrm{K}_{\mathrm{a}, \mathrm{ClOH}}
$$

Deborde and Von Gunten (2008) reported a value of the acid dissociation constant $\mathrm{Ka}_{4}$ of $2.9 \times 10^{-8}\left(\mathrm{pK}_{\mathrm{a}, 4}=7.54\right)$ at $298 \mathrm{~K}$. Consequently, the chlorine speciation depends on several parameters including the $\mathrm{pH}$, the temperature, the chloride concentration and, with a lower importance, the ionic strength. $\mathrm{Cl}_{2}, \mathrm{ClOH}$ and $\mathrm{ClO}^{-}$are called the free chlorine species. Other reactive chlorine species can be formed upon various conditions $\left(\mathrm{Cl}_{3}{ }^{-}, \mathrm{Cl}_{2} \mathrm{O}\right.$, etc.) but their formation are not favored at low chloride concentrations (Doré, 1989). In most chemical conditions applied in water treatment, $\mathrm{Cl}_{2}$ is negligible in solution for $\mathrm{pH}>6$. 
Gunten, 2008). The chlorine reactivity with organic or inorganic compounds depends on the

chlorine and target compounds speciation; so a great $\mathrm{pH}$ dependence of the apparent kinetic

rate constants is expected in many cases. The oxidation reactions usually follow a second-

order kinetic law with partial first-orders for both the free active chlorine concentration and

for the total compound concentration (Deborde and Von Gunten, 2008).

The oxidation of hydrogen sulfide occurs by a complex mechanism which involves many by-products: colloidal sulfur, sulfites, thiosulfates, or sulfates depending on the $\mathrm{pH}$, the temperature and the advancement of the reaction (Bonnin, 1991; Cadena and Peter, 1988; Choppin and Faulkenberry, 1937). Sulfide (oxidation degree -2) is firstly oxidized into sulfur (degree of oxidation 0) which can be further oxidized into thiosulfate (degree of oxidation +2 ) sulfite (degree of oxidation +4 ) and sulfate (degree of oxidation +6 ) depending on the $\mathrm{pH}$ and the residual chlorine concentration (Choppin and Faulkenberry, 1937). Sulfite is directly oxidized in sulfate which requires one equivalent of chlorine for one equivalent of sulfite (Fogelmann et al., 1989). Consequently, at least one equivalent of chlorine is required for the production of sulfur as end-product (Eq. 5) whereas 4 equivalents are necessary for the production of sulfate (Eq. 6):

$$
\mathrm{Na}_{2} \mathrm{~S}+\mathrm{NaOCl}+\mathrm{H}_{2} \mathrm{O} \longrightarrow \mathrm{S}+\mathrm{NaCl}+2 \mathrm{NaOH}
$$

$$
\mathrm{Na}_{2} \mathrm{~S}+4 \mathrm{NaOCl} \stackrel{\text { complete oxidation }}{\longrightarrow} 4 \mathrm{NaCl}+\mathrm{Na}_{2} \mathrm{SO}_{4}
$$

Few studies focus on hydrogen sulfide chlorination due to the high kinetic rates observed, the complex chemistry of these species and the difficulty to analyze sulfur compounds properly. The kinetics of the $\mathrm{H}_{2} \mathrm{~S}$ oxidation in alkaline solutions has been investigated by Bonnin (1991) through reactive absorption. Using a gas-liquid contactor and

$$
-5 / 5-
$$


an excess of sodium hypochlorite in solution, Bonnin determined an apparent kinetic constant of $1.8 \times 10^{8} \mathrm{~L} \mathrm{~mol}^{-1} \mathrm{~s}^{-1}$ between $\mathrm{pH} 9$ and 11 and confirmed that the kinetics is very fast. This determination did not take both chlorine and sulfide speciations into account. Moreover, Biard et al. (2010) demonstrated that Bonnin used a wrong assumption when he neglected the gas-phase resistance to simplify the absorption rate. In 2010 , considering the results of field chemical scrubbing experiments, Biard et al. assessed that the apparent kinetic constant at alkaline $\mathrm{pH}$ below 10.5 could reasonably range between $10^{6}$ and $10^{9} \mathrm{~L}$ $\mathrm{mol}^{-1} \mathrm{~s}^{-1}$. Deborde and Von Gunten (2008) proposed a kinetic constant for the specific reaction of $\mathrm{HS}^{-}$with $\mathrm{ClOH}$ very close to that of sulfite ions in the range $10^{8}-10^{9} \mathrm{~L} \mathrm{~mol}^{-1} \mathrm{~s}^{-1}$. This determination was based on the $\mathrm{HS}^{-}$nucleophilicity assuming a chlorine electrophilic attack similar to those previously described for halides or other anionic inorganic compounds $\left(\mathrm{SO}_{3}{ }^{2-}\right.$ , $\mathrm{I}^{-}, \mathrm{Br}^{-}, \mathrm{Cl}^{-}$and $\left.\mathrm{CN}^{-}\right)$. The specific kinetic constants of $\mathrm{H}_{2} \mathrm{~S}$ reactions with $\mathrm{ClO}^{-}\left(\mathrm{k}=6.7510^{6} \mathrm{~L}\right.$ $\left.\mathrm{mol}^{-1} \mathrm{~s}^{-1}\right)$ and $\mathrm{ClOH}\left(\mathrm{k}=1.6210^{5} \mathrm{~L} \mathrm{~mol}^{-1} \mathrm{~s}^{-1}\right)$ have been studied by reactive absorption in a gas-liquid contactor (Vilmain et al., 2014). The surprising larger value found with $\mathrm{ClO}^{-}$was justified by a two steps mechanism (acid base reaction between $\mathrm{H}_{2} \mathrm{~S}$ and $\mathrm{ClO}^{-}$followed by direct oxidation between $\mathrm{ClOH}+\mathrm{HS}^{-}$). Therefore, these kinetic constants are apparent and probably overestimate the true values.

To satisfactorily design and understand chemical scrubbers applied to $\mathrm{H}_{2} \mathrm{~S}$ treatment, a good knowledge of the kinetics and mechanism of oxidation is necessary. Due to the absence of accurate kinetic data, the scrubbers' design is largely based on the feedback from existing plants more than on a precise demonstration. The goal of this study is then to extend the study of Vilmain et al. (2014) through the determination of the kinetic constant between $\mathrm{HS}^{-}$and $\mathrm{ClOH} / \mathrm{ClO}^{-}$and to be able to calculate the kinetic rate of hydrogen sulfide chlorination in a rather large $\mathrm{pH}$ range at $\mathrm{T}=298 \mathrm{~K}$. The competitive kinetics method has

$$
-6 / 6-
$$


121 been selected. This method has been successfully applied to determine large kinetic 122 constants, especially in the ozonation field (Beltrán, 2004; Biard et al., 2011; Hoigne and 123 Bader, 1983) and is based on the comparison of the consumptions by free chlorine of the 124 target compounds $\left(\mathrm{H}_{2} \mathrm{~S}\right)$ and a reference compound whose kinetic constant is known. The 125 sulfite anion $\mathrm{SO}_{3}{ }^{2-}$ was selected as the reference compound since its kinetic rate should be 126 close to sulfide kinetic rate in a rather large $\mathrm{pH}$ range considering that their nucleophilicities

127 (i.e. their kinetic constants) are similar (Deborde and Von Gunten, 2008). Moreover, the 128 sulfite oxidation mechanism is very simple since 1 equivalent of chlorine is consumed to oxidize directly 1 equivalent of sulfite into sulfate and its oxidation kinetics has been deeply investigated at T = $298 \mathrm{~K}$ (Fogelman et al., 1989). 


\section{MATERIALS AND METHODS}

132

\subsection{Experimental method}

The competitive kinetics method was applied to determine the $\mathrm{H}_{2} \mathrm{~S}$ chlorination kinetics using the sulfite anion $\mathrm{SO}_{3}{ }^{2-}$ as the reference compound. The chlorination of both pure compounds (sulfite and sulfide) was carried out previously to find out the apparent stoichiometries for each compound depending on the initial concentrations. Both chlorinations were performed in a $100 \mathrm{~mL}$ gas-tight syringe (Hamilton) whose needle was replaced by a septum allowing to quickly withdraw and inject samples. A stir bar was placed in the syringe for the subsequent mixing. As mentioned by Biard et al. (2011), this kind of reactor is headspace free to avoid $\mathrm{H}_{2} \mathrm{~S}$ volatilization as well as oxygen dissolution which can consume sulfite anions. Moreover, its volume varies when sampling due to the plunger course which enables to keep a constant pressure inside the reactor.

Fig. 1: Presentation of the experimental method. A schematic representation of the protocol is illustrated in Fig. 1. All solutions were prepared using Ultra Pure Water (UPW) prepared by reverse osmosis using an Elga lab purification unit (resistivity $>18 \mathrm{M} \Omega \mathrm{cm}$ ). UPW was deoxygenated by $\mathrm{N}_{2}(99,999 \%$ with maximum 2 ppmv of residual $\mathrm{O}_{2}$, provided by Air Liquide) bubbling. To avoid $\mathrm{SO}_{3}{ }^{2-}$ oxidation by $\mathrm{O}_{2}$, the sulfite solution was prepared directly in the reactor by adding sodium sulfite. Then $100 \mathrm{~mL}$ of UPW was added to dissolve it. $90 \mathrm{~mL}$ of this solution were drained to keep only 10 $\mathrm{mL}$. Then, $3 \mathrm{~mL}$ of a sulfide solution, a buffer solution and UPW until $98.4 \mathrm{~mL}$ were added with gas-tight glass syringes ( $\mathrm{SGE}$, Australia). Reaction solutions were buffered for experiments at $\mathrm{pH} 6,7,7.5$ and 8 . For $\mathrm{pHs} 9-12$, the initial $\mathrm{pH}$ was set by adding $\mathrm{NaOH}$. The

$$
-8 / 8-
$$


syringe was held horizontally in a thermostatic bath regulated at $25^{\circ} \mathrm{C} \pm 0.2$. After $20 \mathrm{~min}, 1$ $\mathrm{mL}$ of chlorine solution was injected in the reactor using a gas-tight syringe (from SGE). Then, after 2 min of stirring (assuming oxidation is achieved) and complete chlorine consumption, $0.6 \mathrm{~mL}$ of ethanol (99\% purity) was injected in the reactor to stabilize the sulfite ions in the aqueous solution before analyses (de Carvalho and Schwedt, 2000).

We note that sulfite and sulfide can react together to form thiosulfate. This reaction is slow and does not happen during the short time between the mixture preparation and the chlorine injection.

\subsection{Analytical methods}

The $\mathrm{pH}$ was controlled directly after each experiment by a pH-meter type Eutech Instruments Cyberscan 510 ( $\pm 0.01 \mathrm{pH}$ unit tolerance) equipped with a Fisher Scientific probe. The $\mathrm{pH}$ variation due to chlorine addition was found negligible in all cases. The sulfite anions were analyzed using ion chromatography (§ 2.2.2). Since $\mathrm{HS}^{-}$and $\mathrm{SO}_{3}{ }^{2-}$ have the same retention time, $\mathrm{H}_{2} \mathrm{~S}$ was previously stripped from a sample of the solution set at neutral $\mathrm{pH}$ by $\mathrm{N}_{2}$ bubbling.

\subsubsection{Hydrogen sulfide analysis}

The methylene blue spectrophotometric method has been evaluated and recommended by various researchers for sulfide quantification (Fogo and Popowsky, 1949; Reese et al., 2011). N,N-Dimethyl-1,4-phenylenediamine (DMPD) reacts with hydrogen sulfide to form a compound which changes into blue leucomethylene. This compound, oxidized under acidic conditions in the presence of an oxidant (usually Fe(III)), forms methylene blue. This method was used in combination with the standard addition method for a higher accuracy of $\mathrm{H}_{2} \mathrm{~S}$ measurement. The limit of quantification and detection are 
approximately $0.3 \mathrm{ppm}$ and $0.1 \mathrm{ppm}$. Statistic methods validated the repeatability, reproducibility and the reliability of the method.

\subsubsection{Determination of the sulfite and sulfate anions' concentrations by ionic} chromatography

Dionex-DX 120 Ion Chromatography, equipped with IonPac ${ }^{\circledR}$ AG 18 (4 mm ×50 mm) guard column and AS18 analytical column $(4 \mathrm{~mm} \times 250 \mathrm{~mm})$, was used for $\mathrm{SO}_{3}{ }^{2-}$ quantification. Filtered samples (syringe filter with prefilter Minisart from Sartorius, membrane: cellulose acetate; threshold: $0.45 \mu \mathrm{m}$ ) were injected (250 $\mu \mathrm{L}$ samples). $\mathrm{KOH}$ eluent (flow rate of $1.06 \mathrm{~mL} \mathrm{~min}^{-1}$ ) was degassed by vacuum and produced electrochemically in-line. Ramped eluent concentration was used with $10 \mathrm{mmol} \mathrm{L}^{-1}$ (0-10 min), 10-45 $\mathrm{mmol} \mathrm{L}^{-1}$ (10-25 $\mathrm{min})$ and $45 \mathrm{mmol} \mathrm{L}{ }^{-1}$ (25-35 min). Data acquisition was performed by Chromeleon software. The resolution between sulfate and sulfite peaks was equal to 1.6.

Sulfite is easily oxidizable and is particularly unstable in the presence of oxygen. This oxidation was prevented before the reaction step by preparing the sulfite solution in the 100 $\mathrm{mL}$ syringe with deoxygenated water. Only a small amount of $\mathrm{O}_{2}$ can dissolve in the solution during the sample preparation prior to ionic chromatography. Therefore, ethanol was selected to stabilize the sulfite anions immediately after the reaction (de Carvalho and Schwedt, 2000). Using non-deoxygenated UPW, the sulfite anion concentration decreases quickly (38.0\% of recovery after $350 \mathrm{~min}$ ) whereas using deoxygenated UPW in the syringe enabled this phenomenon to be limited. An ethanol concentration of $0.1 \mathrm{~mol} \mathrm{~L}^{-1}$ is necessary to achieve a negligible sulfite consumption (99.4\% of recovery after $350 \mathrm{~min}$ ). 
199

200

201

202

203

204

207

208

209

210

211

212

213

214

215

216

\subsubsection{Chlorine analysis}

Chlorine was measured after sampling using the iodometric method. $5 \mathrm{~mL}$ of glacial acetic acid and $1 \mathrm{~g}$ of potassium iodide was added to the sample. Thereafter, the sample was titrated with $0.1 \mathrm{M}$ or $0.001 \mathrm{M}$ sodium thiosulfate (Normadose ${ }^{\circledR}$ VWR).

\subsection{Reagents}

All chemical products had an analytical grade. Sodium sulfide nonahydrate, sodium sulfite, sodium thiosulfate, sodium hypochlorite, potassium hydrogen phtalate, potassium sulfate, acetic acid, absolute ethanol and acetone were purchased from Acros Organics (Belgium). Sodium hydroxide was purchased from Fischer Scientific, potassium iodate from Labogros, potassium dihydrogen phosphate from Panreac Quimica, and tris(hydroxymethyl)aminomethane from Merck. Hydrochloric acid was obtained from Prolabo. Hydrochloric acid $(0.01,0.1,1 \mathrm{M})$ was prepared using Analar Normapur ${ }^{\circledR}$ solutions. The hydrogen sulfide solutions were prepared daily by serial dilutions.

Buffer solutions were prepared by dissolving appropriate amounts of three chemical products in Ultra Pure Water: potassium hydrogen phthalate, potassium dihydrogen phosphate and (hydroxymethyl)aminomethane completed with $\mathrm{HCl}$ or $\mathrm{NaOH}$. 
219 The apparent stoichiometric coefficients, $\delta$ and $\gamma$, of the reactions between sulfite and sulfide anions with chlorine at $25^{\circ} \mathrm{C}$ were determined through the chlorination of each pure compound:

$\delta=\frac{[\mathrm{NaOCl}]_{t=0}-[\mathrm{NaOCl}]_{\text {final }}}{\left[\mathrm{Na}_{2} \mathrm{~S}\right]_{t=0}-\left[\mathrm{Na}_{2} \mathrm{~S}\right]_{\text {final }}}$

$\gamma=\frac{[\mathrm{NaOCl}]_{t=0}-[\mathrm{NaOCl}]_{\text {final }}}{\left[\mathrm{Na}_{2} \mathrm{SO}_{3}\right]_{t=0}-\left[\mathrm{Na}_{2} \mathrm{SO}_{3}\right]_{\text {final }}}$

reagents'concentrations, $\mathrm{Ra}_{\text {sulfide }}$ and $\mathrm{Ra}_{\text {sulfite, }}$, defined as:

$R a_{\text {suffide }}=\frac{\left[\mathrm{Na}_{2} \mathrm{~S}\right]_{t=0}}{[\mathrm{NaOCl}]_{t=0}}$

$$
R a_{\text {sulfite }}=\frac{\left[\mathrm{Na}_{2} \mathrm{SO}_{3}\right]_{t=0}}{[\mathrm{NaOCl}]_{t=0}}
$$


234

235

236

237

the oxidation (Choppin and Faulkenberry, 1937) which was confirmed by the detection of sulfate anions by ionic chromatography. In the other hand, when sulfide was in sufficient excess $\left(R a_{\text {sulfide }}>3\right)$, the oxidation was restricted to the parent compound. One equivalent of chlorine was consumed for one equivalent of sulfide $(\delta=1)$ improving the selectivity of the reaction. Indeed, in this case, the end-product should be only sulfur which is in agreement with the literature (Choppin and Faulkenberry, 1937). Moreover, no sulfite and sulfate anions were detected by ionic chromatography. Consequently, to ensure no sulfite anions produced during sulfide anion oxidation and no interaction during mixture experiments, $R a_{\text {sulfide }}$ must be larger than approximately 3 . The $\mathrm{pH}$ seems to have a slight effect only when the initial chlorine concentration was larger than the sulfide anion concentration.

Otherwise, since sulfite anions is directly oxidized into sulfate anions, which cannot be further oxidized by chlorine (Fogelmann et al., 1989), one equivalent of chlorine was consumed for one equivalent of sulfite $(\gamma=1)$, whatever the value of $R a_{\text {sulfite }}$ applied (Fig. 2).

The rather large dispersion of the points around 1 is due to the quite low sulfite anion analytical methods precision (sulfite instability in solution). This low precision has no influence in the competitive kinetics method results analysis (section 3.2).

Fig. 2: Evolution of $\delta$ and $\gamma$ vs. respectively $R a_{\text {sulfide }}$ and $R a_{\text {sulfite }}$

3.2 Chlorination of sulfide/sulfite anion mixtures: determination of the relative apparent kinetic constant

Chlorination of the sulfide/sulfite mixture was performed between $\mathrm{pH} 6$ and 12. Each experiment was triplicated with $R a_{\text {sulfite }} \approx 1.5$ and $R a_{\text {sulfide }} \approx 2.7$. These ratios were optimal to accurately measure the sulfite and sulfide consumptions and to optimize the sulfide oxidation selectivity. Chlorine was the limiting reagent and was not detected at the end of each experiment. 

be checked. According to Eqs 9 and 10:

260

$$
[\mathrm{NaOCl}]_{t=0}-[\mathrm{NaOCl}]_{\text {final }}=\delta\left(\left[\mathrm{Na}_{2} \mathrm{~S}\right]_{t=0}-\left[\mathrm{Na}_{2} \mathrm{~S}\right]_{\text {final }}\right)+\gamma\left(\left[\mathrm{Na}_{2} \mathrm{SO}_{3}\right]_{t=0}-\left[\mathrm{Na}_{2} \mathrm{SO}_{3}\right]_{\text {final }}\right)
$$

261

262

264

265

266

267

Figure 3: Sulfite and sulfide consumptions $(\Delta[i])$ during competitive kinetics trials.

The oxidation removal efficiencies of sulfite and sulfide were in the range $10-25 \%$ and were significantly measurable. Figure 3 presents a histogram of the average consumed concentrations $(\Delta[i])$ of hydrogen sulfide and sulfite for each $\mathrm{pH}$ studied. The mass balance was well respected by taking $\gamma$ and $\delta=1$, except at $\mathrm{pH} 10$ at which a lower sulfide and/or sulfite consumption was measured.

Assuming that partial orders are equal to 1 (Deborde and von Gunten, 2008), the

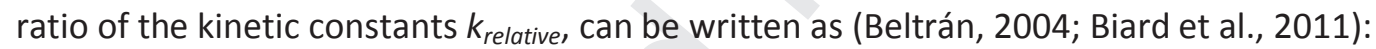

$k_{\text {relative }, 1}=\frac{k_{a p p}^{\text {sulfide }}}{k_{\text {app }}^{\text {sulfite }}}=\frac{\delta}{\gamma} \times\left(\frac{\operatorname{Ln} \frac{\left[\mathrm{Na}_{2} \mathrm{~S}\right]_{t=0}}{\left[\mathrm{Na}_{2} \mathrm{~S}\right]_{\text {final }}}}{\operatorname{Ln} \frac{\left[\mathrm{Na}_{2} \mathrm{SO}_{3}\right]_{t=0}}{\left[\mathrm{Na} \mathrm{SO}_{3}\right]_{\text {final }}}}\right)$

Equation 14 can be used by knowing just the concentrations of the two target compounds (i.e the initial oxidant concentration is not required). In this study, the oxidant concentration was also measured, enabling to calculate $\mathrm{k}_{\text {relative }}$ by two additional equations deduced from the mass balance equation (Biard et al., 2011):

$k_{\text {relative }, 2}=\frac{k_{a p p}^{\text {sulfide }}}{k_{\text {app }}^{\text {sulfite }}}=\frac{\delta}{\gamma} \times\left(\frac{\operatorname{Ln} \frac{\left[\mathrm{Na}_{2} \mathrm{~S}\right]_{t=0}}{\left[\mathrm{Na}_{2} \mathrm{~S}\right]_{\text {final }}}}{\left[n \frac{\left[\mathrm{Na}_{2} \mathrm{SO}_{3}\right]_{t=0}}{\left[\mathrm{Na}_{2} \mathrm{SO}_{3}\right]_{t=0}-[\mathrm{NaOCl}]_{t=0}+\left[\mathrm{Na}_{2} \mathrm{~S}\right]_{t=0}-\left[\mathrm{Na}_{2} \mathrm{~S}\right]_{\text {final }}}\right.}\right)$ 
$k_{\text {relative }, 3}=\frac{k_{a p p}^{\text {sulfide }}}{k_{a p p}^{\text {sulfite }}}=\frac{\delta}{\gamma} \times\left(\frac{\operatorname{Ln} \frac{\left[\mathrm{Na}_{2} \mathrm{~S}\right]_{t=0}}{\left[\mathrm{Na}_{2} \mathrm{~S}\right]_{t=0}-[\mathrm{NaOCl}]_{t=0}+\left[\mathrm{Na}_{2} \mathrm{SO}_{3}\right]_{t=0}-\left[\mathrm{Na}_{2} \mathrm{SO}_{3}\right]_{\text {final }}}}{\operatorname{Ln} \frac{\left[\mathrm{Na}_{2} \mathrm{SO}_{3}\right]_{t=0}}{\left[\mathrm{Na}_{2} \mathrm{SO}_{3}\right]_{\text {final }}}}\right)$

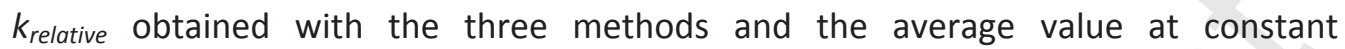
temperature $\left(25 \pm 0.2^{\circ} \mathrm{C}\right)$ is shown in Fig. 4. Except at $\mathrm{pH}=10$, the values of $k_{\text {relative }}$ found were close whatever the equation used since the mass balance was well respected. At $\mathrm{pH}=$ 10, a stronger dispersion was observed but the average value was consistent with the value obtained by Eq. 14 like the other values of $\mathrm{pH}$. Consequently, the average value of $k_{\text {relative }}$ is reliable. Depending on the $\mathrm{pH}, k_{\text {relative }}$ is in the range $1-2$ confirming that sulfite and sulfide oxidation kinetic rate are close, even at $\mathrm{pH}$ close to the neutrality, at which acidic species $\left(\mathrm{H}_{2} \mathrm{~S}, \mathrm{HSO}_{3}{ }^{-}\right)$are present and can bias this observation. Indeed, according to Deborde and Von Gunten (2008), $\mathrm{HS}^{-}$and $\mathrm{SO}_{3}{ }^{2-}$ oxidation kinetic rates are expected to be similar but no data are available for $\mathrm{H}_{2} \mathrm{~S}$ and $\mathrm{HSO}_{3}{ }^{-}$ones. The trend of Fig. 4 remains complicated to justify since many chemical reactions are a priori involved. The next section focuses on sulfite oxidation kinetic rate analysis prior to sulfide kinetic rate determination.

\subsection{Sulfite oxidation kinetics}

The sulfite anion is a basic species in equilibrium with the hydrogen sulfite $\left(\mathrm{HSO}_{3}{ }^{-}\right)$.

The apparent $\mathrm{pK}_{\mathrm{a}}$ value is included in the range 6.91-7.2 at $298 \mathrm{~K}$, depending on the hydrogen sulfite concentration since $\mathrm{HSO}_{3}{ }^{-}$exists in two tautomeric forms (Rhee and Dasgupta, 1985). At low sulfite concentration $\left(<10^{-4} \mathrm{~L} \mathrm{~mol}^{-1} \mathrm{~s}^{-1}\right), \mathrm{pK}_{\mathrm{a}, 5}=6.91 . \mathrm{H}_{2} \mathrm{SO}_{3}\left(\mathrm{H}_{2} \mathrm{O}+\right.$ $\mathrm{SO}_{2}$ ) is present only at very acidic $\mathrm{pH}$ and is neglected in this discussion. The oxidation mechanism of the sulfite anion with chlorine involves a priori several acid-base (Reactions 17 
298

299

300

301

302

303

304

305

306

307

308

309

310

311

312

313

314

315

316

317

318

to 21 ) and oxidation reactions (Reactions 22 to 24 ) synthesized Table 1 . The potential reaction between $\mathrm{ClO}^{-}$and $\mathrm{HSO}_{3}{ }^{-}$has not been considered since it involves a weak base and a weak acid whose coexistence in solution is unlikely. Moreover, the kinetic rate of this reaction should be low since $\mathrm{ClO}^{-}$and $\mathrm{HSO}_{3}^{-}$are respectively poorer electrophile and nucleophile than $\mathrm{ClOH}$ and $\mathrm{SO}_{3}{ }^{2-}$ (Fogelman et al., 1989). Fogelman et al. determined the kinetic constants of reactions 22 and 23 using the stopped-flow method at $298 \mathrm{~K}$ (Fogelman et al., 1989). Even if hypochlorous acid $(\mathrm{ClOH})$ does not predominate at $\mathrm{pH}>7.54$, since $\mathrm{k}_{23}$ $>\mathrm{k}_{22}$, sulfite anion is more oxidized by $\mathrm{ClOH}$ than $\mathrm{ClO}^{-}$for $\mathrm{pH}<12-12.1$. Their study was conducted at $\mathrm{pH}>9.5$, at which reaction 24 which involves two acids is unexpected and unfortunately $k_{24}$ is unknown. For the rest of the discussion, this reaction was neglected since $\mathrm{HSO}_{3}{ }^{-}$should be less reactive than $\mathrm{SO}_{3}{ }^{2-}$ and the study was mainly conducted in the $\mathrm{pH}$ range (> 6.91-7.2) at which $\mathrm{SO}_{3}{ }^{2-}$ is predominant. This assumption will be confirmed in the section 3.2.5. Kinetic constants of bimolecular proton transfer reactions (Eqs 17 to 21) are not precisely known. According to Eigen (1964), the orders of magnitude of the kinetic constants for recombination of a base with $\mathrm{H}^{+}$(reverse reactions 18 and 20) and of an acid with $\mathrm{HO}^{-}$(Reactions 17 and 19 ) are respectively typically $10^{10}-10^{11}$ and $10^{9}-10^{11} \mathrm{~L} \mathrm{~mol}^{-1} \mathrm{~s}^{-1}$ (Eigen, 1964). The ratio of them for a given acid/base couple is between 2 and 3 in many cases. Fogelman et al. used with a good agreement a value of $\mathrm{k}_{17}=3 \times 10^{9} \mathrm{~L} \mathrm{~mol}^{-1} \mathrm{~s}^{-1}$ in their simulations (Fogelman et al., 1989). Taking this into consideration, $\mathrm{k}_{17}, \mathrm{k}_{-18}, \mathrm{k}_{19}$ and $\mathrm{k}_{-20}$ are respectively set to the values presented in Table 1 . The rather large value of $k_{-20}$ has been chosen equal to $\mathrm{k}_{30}$ by analogy $\left(\mathrm{H}_{2} \mathrm{~S}\right.$ dissociation, Table 5$)$. Considering that $\mathrm{pK}_{\mathrm{a}, 4}-\mathrm{pK}_{\mathrm{a}, 5} \approx 0.5$, $\mathrm{k}_{21}$ can be set to $3 \times 10^{8} \mathrm{~L} \mathrm{~mol}^{-1} \mathrm{~s}^{-1}$ according to Eigen (1964).

In a batch reactor, at constant temperature and volume, the kinetic law of total sulfite consumption can be written: 
$-\frac{\mathrm{d}\left[\mathrm{SO}_{3}^{2-}\right]_{T}}{\mathrm{~d} t}=k_{22}\left[\mathrm{SO}_{3}^{2-}\right][\mathrm{ClO}]+k_{23}\left[\mathrm{SO}_{3}^{2-}\right][\mathrm{ClOH}]$

The kinetic rate of this reaction was expected to decrease with the $\mathrm{pH}$ since the

hypochlorous acid concentration decreased. The temptation is high to consider that both acid/base couples are in equilibrium to introduce the total sulfite and hypochlorite concentrations and the $\mathrm{pK}_{\mathrm{a}}$ values:

$-\frac{\mathrm{d}\left[\mathrm{SO}_{3}^{2-}\right]_{T}}{\mathrm{~d} t}=k_{a p p, c a l}^{\text {sulfite }} \times\left[\mathrm{SO}_{3}^{2-}\right]_{T}[\mathrm{ClO}]_{T}$

with $k_{a p p, c a l}^{\text {sulfite }}=\frac{k_{22}}{\left(1+10^{p K_{a, 4}-p H}\right)\left(1+10^{p K_{a, 5}-p H}\right)}+\frac{k_{23}}{\left(1+10^{p H-p K_{a, 4}}\right)\left(1+10^{p K_{a, 5}-p H}\right)}$

With this assumption, at a constant $\mathrm{pH}$, the kinetics is second-order with a calculated apparent kinetic constant $k_{a p p, c a l}^{\text {sulfite }}$ (whose evolution versus the $\mathrm{pH}$ is represented in Fig. 5). The subscripts "cal" means that $k_{a p p}$ has been calculated through Eq 27 . Then, the chlorine and the sulfite concentration-time profiles can be determined by Eq. 28, which is the classical solution of the differential equation for a second-order kinetics in a batch reactor:

$T=k_{\text {app }}^{\text {sulfite }} \times t$ with $T=\frac{1}{\left[\mathrm{ClO}^{-}\right]_{T, 0}-\left[\mathrm{SO}_{3}^{2-}\right]_{T, 0}} \ln \frac{\left[\mathrm{SO}_{3}^{2-}\right]_{T, 0}\left[\mathrm{ClO}^{-}\right]_{T}}{\left[\mathrm{SO}_{3}^{2-}\right]_{T}\left[\mathrm{ClO}^{-}\right]_{T, 0}}$

Table 1

Fig. 5: Effect of $\mathrm{pH}$ on $k_{a p p, c a l}$ for sulfite and sulfide oxidations. $k_{a p p, c a l}$ was calculated with Eq. 27 and 38 whereas $k_{a p p, s i m}$ was calculated through the numerical simulations (using the conditions of Table 2). The blue and green areas delimit zones where $k_{\text {app }}$ for respectively sulfite and sulfide should be located for a wide range of experimental conditions. 
341 instantaneous compared to oxidation reactions to maintain sulfite and chlorine species

342 equilibrium over all times. This assumption can be controversial, especially at $\mathrm{pH}$ close to the neutrality, where the kinetic rate is maximal. To assess it, the concentration-time profile of each species involved in reactions 17 to 23 has been determined using the software COPASI developed by the Virginia Bioinformatics Institute (USA) and the universities of Heidelberg (Germany) and Manchester (UK). This open-source software is dedicated to the numerical resolution of differential equations systems found in biological and chemical kinetics. Examples of concentration-time and reaction rate-time profiles returned by COPASI are presented in appendix. An analytical solution is not possible, especially since steady-state approximations (Bodenstein) are not possible. $\mathrm{HO}^{-}$and $\mathrm{H}^{+}$concentrations have been fixed to their initial values since a buffer is added to maintain a constant $\mathrm{pH}$ (except at $\mathrm{pH} \geq 9$ at which it is not necessary). Different operating conditions $(\mathrm{pH}$, total sulfite and chlorine concentrations) have been applied to assess their influence. For each simulation, the time course is discretized into 500 intervals until a degree of advancement of $90 \%$ is reached $\left(t_{90}\right.$

- to check if the kinetic rate is second-order (using appropriated statistic criteria such as the determination coefficient $R^{2}$ and the F-test value);

- if so, to determine the apparent $2^{\text {nd }}$ order kinetic constants (called $k_{a p p, s i m}$ ) from the slope; 
(at the chlorine and sulfite initial concentrations used in the section 3.2.2), the order of magnitude of the initial concentrations and the initial concentrations ratio (Tables 3 and 4 simulations were performed at $\mathrm{pH} 8$ since it is the $\mathrm{pH}$ which presents the largest discrepancy between $k_{a p p, c a l}$ and $\left.k_{a p p, s i m}\right)$. Except for a few limited cases (Simulations \#11 and \#15), the reaction was predicted to follow second-order kinetics. At $\mathrm{pH}$ lower than $10, k_{\text {app,sim }}$ was always lower than $k_{a p p, c a l .}($ Table 2 ), which emphasizes that the kinetic rate was limited by proton transfer reactions. Fig A.2 clearly highlights that the $\mathrm{ClOH}$ consumption rate by reaction 23 was larger than its reformation rate due to reactions 17, 18 and 21 . Even if $\mathrm{ClOH}$ and $\mathrm{ClO}^{-}$were in equilibrium at the beginning of the simulation, the ratio $[\mathrm{ClOH}] /\left[\mathrm{ClO}^{-}\right]$ decreased with time whereas the $\mathrm{pH}$ stayed constant. Consequently, using Eq. 27 can lead to severe overestimations of the kinetic rate and by the way bias the results of the competitive study. For example, with the initial conditions of simulation \#4, the time necessary to achieve a degree of advancement of $90 \%$ using $k_{a p p, c a l}$ was $0.46 \mathrm{~ms}$, whereas the time simulated was $0.98 \mathrm{~ms}$. This observation is particularly true for $\mathrm{pH}$ ranging between 7 and 9 where the kinetic rate is maximal. When the $\mathrm{pH}$ exceeds 10 , the oxidation kinetic rate decreased and the $\mathrm{ClOH}$ consumption was more easily compensated, which enabled to maintain more easily the species equilibrium. In this case, the apparent kinetic constant calculated by Equation 27 was exact and the reaction time necessary to consume $90 \%$ of the limiting reagent (chlorine) increased beyond $1 \mathrm{~s}$.

Even if the kinetic rate of the reaction increases with the initial concentrations ( $t_{90}$ decreases), the value of $k_{a p p, s i m}$ decreases (Table 3). Indeed, with larger initial concentrations, the $\mathrm{HSO}_{3}{ }^{-} / \mathrm{SO}_{3}{ }^{2-}$ equilibrium is more difficult to maintain since the kinetic rate is larger. By the way, $k_{a p p, s i m}$ tends towards $k_{a p p, c a l}$ when the initial concentration decreases. When sulfite 
387 is the limiting reagent (simulation \#13), sulfite equilibrium is more difficult to maintain. The 388 apparent kinetic constant is rather poorly influenced by the initial concentrations ratio 389 (Table 4) except when chlorine is added in great excess. In this case, the kinetic rate is 390 pseudo first-order, the chlorine species stay obviously at the equilibrium and the simulated 391 apparent kinetic constant tends towards the calculated one.

392

393
Table 2

Table 3

Table 4 
Table 5

As for the sulfite anions, the sulfide oxidation (Table 5) a priori involves several acid-

base reactions (17, 18 and 29 to 31 ) and pure oxidation reactions (32 to 34). Only the first oxidation step which leads to elemental sulfur was considered since the initial concentrations ratio ( $\left.R a_{\text {sulfide }}\right)$ was carefully selected. Moreover, in the $\mathrm{pH}$ range studied (6$12), S^{2-}$ can be neglected. Based on these assumptions, the kinetic law of total sulfide 402 consumption can be written:

403

$-\frac{\mathrm{d}\left[\mathrm{H}_{2} \mathrm{~S}\right]_{T}}{\mathrm{~d} t}=-\frac{\mathrm{d}\left[\mathrm{H}_{2} \mathrm{~S}\right]}{\mathrm{d} t}-\frac{\mathrm{d}\left[\mathrm{HS}^{-}\right]}{\mathrm{d} t}=-\frac{\mathrm{d}\left[\mathrm{ClO}^{-}\right]}{\mathrm{d} t}-\frac{\mathrm{d}[\mathrm{ClOH}]}{\mathrm{d} t}$

404

$-\frac{\mathrm{d}\left[\mathrm{H}_{2} \mathrm{~S}\right]_{T}}{\mathrm{~d} t}=k_{32}\left[\mathrm{H}_{2} \mathrm{~S}\right]\left[\mathrm{ClO}^{-}\right]+k_{33}\left[\mathrm{H}_{2} \mathrm{~S}\right][\mathrm{ClOH}]+k_{34}\left[\mathrm{HS}^{-}\right]\left[\mathrm{ClO}^{-}\right]+k_{35}\left[\mathrm{HS}^{-}\right][\mathrm{ClOH}]$

405

If chlorine and sulfide species are in equilibrium with their respective conjugated 406 species, then:

$-\frac{\mathrm{d}\left[\mathrm{H}_{2} \mathrm{~S}\right]_{T}}{\mathrm{~d} t}=k_{a p p, \text { cal }}^{\text {sulfide }} \times\left[\mathrm{H}_{2} \mathrm{~S}\right]_{T}[\mathrm{ClO}]_{T}$

$407 \quad$ With $k_{a p p, c a l}^{\text {suffide }}=\frac{k_{32}}{\left(1+10^{p K_{a, 4}-p H}\right)\left(1+10^{p H-p K_{a, 1}}\right)}+\frac{k_{33}}{\left(1+10^{p H-p K_{a, 4}}\right)\left(1+10^{p H-p K_{a, 1}}\right)}$

$+\frac{k_{34}}{\left(1+10^{p H-p K_{a, 4}}\right)\left(1+10^{p H-p K_{a, 1}}\right)}+\frac{k_{35}}{\left(1+10^{p H-p K_{a, 4}}\right)\left(1+10^{p K_{a, 1}-p H}\right)}$

For the sulfite oxidation, $k_{a p p, c a l}$ and $k_{a p p, s i m}$ are equal only for $\mathrm{pH} 11$ and 12 (Table 2).

409 Consequently, $k_{\text {relative }}$ should be used to study the sulfide oxidation only at these $\mathrm{pH} . k_{a p p, \text { exp }}$

410 for the sulfide oxidation can be extrapolated from $k_{\text {relative }}$ (Eqs 14-16) and $k_{a p p, c a l}^{\text {sulfie }}$ (Eq. 27): 

objective function:

$415 \operatorname{Min}\left(F_{i}\right.$ at $\mathrm{pH}=11+F_{i}$ at $\left.\mathrm{pH}=12\right)$ With $F_{i}=\left(\frac{k_{a p, \text { cal }}^{\text {sulfide }}-k_{a p p, \exp }^{\text {sulfide }}}{k_{a p p, \exp }^{\text {sulfide }}}\right)^{2}$ $\mathrm{k}_{33}$ can be set between 0 and $10^{4} \mathrm{~L} \mathrm{~mol}^{-1} \mathrm{~s}^{-1}$ with a very restricted influence (Table 6). In Table $6, \mathrm{R}_{33}$ represents the following ratio:

invalidated, as expected, the value determined by Bonnin (1991). The very weak sensitivity of the model to $k_{33}$ emphasizes that reaction 33 (sulfide oxidation by hypochlorite anion) is unlikely or very limited, at least at $\mathrm{pH} \leq 12$, even if the $\mathrm{ClOH}$ concentration is low at basic $\mathrm{pH}$. Consequently, the value of $k_{33}$ cannot be determined with a sufficient confidence degree. It justifies why $\mathrm{k}_{\text {relative }}$ is larger than 1 at $\mathrm{pH} 11$ but lower than 1 at $\mathrm{pH} 12$. Indeed, at $\mathrm{pH} 12$, sulfite is oxidized simultaneously by $\mathrm{ClO}-$ and $\mathrm{ClOH}$. main conclusions apply for both compounds. The sulfide oxidation is limited by acid-base reactions $(17,18,29-31)$ at $\mathrm{pH}$ lower than 10, especially when $\mathrm{pH}$ ranges between 6 and 9.

431 Therefore, it confirms that it was pertinent to use only the results obtained at pH 11 and 12 432 to determine $k_{35}$ by numerical resolution. The simulation at $\mathrm{pH} 6$ (simulation \#16) 433 demonstrates that reactions 32 and 34 can be neglected whatever the $\mathrm{pH}$. Indeed, the 
434

435

436

437

438

reaction rate of reaction 32 does not exceed $2 \%$ of the reaction rate of reaction 35 (obtained through simulations) when reaction 34 is absolutely negligible.

Table 6

Table 7

\subsection{Discussion}

$\mathrm{k}_{35}$ was calculated using $k_{\text {relative }}$ at $\mathrm{pH} 11$ and 12 . When the $\mathrm{pH}$ ranges between 6 and

11 , the experimental value of $k_{\text {relative }}$ follows a very special trends. Using the values of $k_{a p p, c a l}$ (Eqs 27 and 38) and $k_{\text {app,sim }}$ (Tables 2 and 7), $k_{\text {relative }}$ can be recalculated twice and compared to the experimental value $\left(k_{\text {relative,exp }}\right)$ :

$k_{\text {relative,cal }}=\frac{k_{a p p, c a l}^{\text {sulfide }}}{k_{a p p, c a l}^{\text {sulfite }}}$

$k_{\text {relative,sim }}=\frac{k_{a p p, \text { sim }}^{\text {sulfide }}}{k_{a p p, \text { sim }}^{\text {sulfite }}}$

Figure 6: Comparison between the experimental $k_{\text {relative }}$ values and the calculated and simulated ones.

On the one hand, the value of $k_{\text {relative,cal }}$ is totally in disagreement with $k_{\text {relative,exp }}$ (Fig.

6). This results was expected since $k_{a p p, c a l}$ is determined assuming that acid-base species stays at the equilibrium, which is not valid at $\mathrm{pH}$ lower than 10 . On the other hand, the value of $k_{\text {relative,sim }}$ follows the same trend than $k_{\text {relative }}$ at basic $\mathrm{pH}$ which is probably not a coincidence. The agreement remains imperfect but one has to consider that $k_{\text {relative }}$ suffers from experimental uncertainties whereas $k_{a p p, s i m}$ is calculated with estimated values of the kinetic constants of numerous acid-base reactions. Moreover, there is a potential uncertainty concerning $\mathrm{pK}_{\mathrm{a}, 5}$.

Table 8 
458 to be confirmed:

$459-k_{\text {relative,sim }}$ and $k_{\text {relative,exp }}$ present an interesting correlation. However, the values of

$460 \quad k_{a p p, s i m}$ are determined with estimated values of the different acid-base reactions (17-21

461 and 29-31). What is the sensitivity of the values of $k_{a p p, s i m}$ to these estimated kinetic

462 constants? To answer to this question, $k_{a p p, s i m}$ for sulfite and sulfide have been

463 recalculated at $\mathrm{pH} 6$ with underestimated and overestimated values of the kinetic

464 constants (Table 8). On the one hand, the results demonstrate that $k_{a p p, s i m}$ is not so

465 sensitive to theses values (especially for sulfide). At least, it does not change the

466 conclusions of the numerical resolutions. The most influential kinetic constants are those

467 of reactions 21 and 31 . On the other hand, the influence on $k_{\text {relative,sim }}$ is rather important

$468\left(k_{\text {relative, sim }}=1.81\right.$ and 1.26 respectively using simulations $24+26$ and $\left.25+27\right)$ and can justify

469 the disagreement observed at this $\mathrm{pH}$ between $k_{\text {relative,exp }}$ and $k_{\text {relative,sim. }}$

470 - The potential reactions between $\mathrm{ClOH}$ and $\mathrm{ClO}^{-}$and $\mathrm{S}^{2-}$ were neglected; this hypothesis

471 required to be discussed more deeply. A possible influence of these two reactions is

472 expected only at very basic $\mathrm{pH}$. Concerning the reaction between $\mathrm{ClOH}$ and $\mathrm{S}^{2-}$, their

473 respective predominance domains are far apart. By the way, assuming a probably

474 overestimated kinetic constant of $5 \times 10^{9} \mathrm{~L} \mathrm{~mol}^{-1} \mathrm{~s}^{-1}, k_{\text {app, cal }}$ at $\mathrm{pH} 12$ goes from $4.210^{-4}$ to

$4754.410^{-4} \mathrm{~L} \mathrm{~mol}^{-1} \mathrm{~s}^{-1}$ which confirms that this reaction can be neglected at $\mathrm{pH}$ lower than 12 .

476 The potential reaction between $\mathrm{S}^{2-}$ and $\mathrm{ClO}^{-}$involves species whose coexistence domains

477 are concomitant. However, it would imply a collision between two weak bases whose one

478 of them carries two negative charges and consequently which requires exceeding an

479 important electrostatic repulsion force. With a probably overestimated value of the 480 kinetic constants of $510^{5} \mathrm{~L} \mathrm{~mol}^{-1} \mathrm{~s}^{-1}$ (maximal order of magnitude encountered between 
$481 \mathrm{ClO}^{-}$and any species), $k_{a p p, c a l}$ goes from $4.210^{4}$ to $5.010^{4} \mathrm{~L} \mathrm{~mol}^{-1} \mathrm{~s}^{-1}$ at pH 12 . It confirms 482 that the reaction between $\mathrm{ClO}^{-}$and $\mathrm{S}^{2-}$ is unlikely at least at $\mathrm{pH}$ lower than 12 . Moreover, 483 a low $\mathrm{pK}_{\mathrm{a}}$ has been considered in this calculation (13.78 according to Stephens and Cobble 484 (1971)) even if the most recent studies seem to confirm that this value is up to 17 at $298 \mathrm{~K}$ 485 (Migdisov et al., 2002).

- Reaction 24 was neglected between $\mathrm{pH}=6$ and $\mathrm{pH}=12$. This assumption must be

487 demonstrated. It involves two weak acids with compatible predominance domains. 488 Simulation \#1 $(\mathrm{pH}=6)$ performed with this additional reaction provides the following 489 results:

$\mathrm{f} \mathrm{k}=10^{7} \mathrm{~L} \mathrm{~mol}^{-1} \mathrm{~s}^{-1}$, the kinetic rate due to this reaction remains lower than $10 \%$ compared to the kinetic rate of the reaction between $\mathrm{ClOH}$ and $\mathrm{SO}_{3}{ }^{2-}$.

$\mathrm{f} \mathrm{k}=10^{8} \mathrm{~L} \mathrm{~mol}^{-1} \mathrm{~s}^{-1}$, the kinetic rate due to this reaction exceeds the kinetic rate of the reaction between $\mathrm{ClOH}$ and $\mathrm{SO}_{3}{ }^{2-}$. However, this order of magnitude remains unexpected regarding the value between $\mathrm{SO}_{3}{ }^{2-}$ and $\mathrm{ClOH}$ and considering that $\mathrm{HSO}_{3}{ }^{-}$is less electrophilic. Moreover, in this case, a huge drop of $k_{\text {relative }}$ in Fig. 6 would have been observed at $\mathrm{pH} 6$. Therefore, we can assume that the potential reaction between $\mathrm{HSO}_{3}{ }^{-}$and $\mathrm{ClOH}$ can be neglected at $\mathrm{pH}$ larger than 6-7. 
500

501

502

503

504

505

506

507

508

509

510

511

512

513

514

515

516

\section{CONCLUSIONS}

Finding a reliable chemical oxidation method requires the knowledge of the reaction kinetics. The objective of this research was to assess the kinetics of sulfide oxidation by chlorine in a wide $\mathrm{pH}$ range (6-12). There are few reliable studies of this reaction studied in the literature, mainly because the large observed kinetic rates makes such studies difficult. The competitive kinetics method using sulfite as the reference compound has been selected. Speciations of chlorine, sulfite and sulfide is rather complex since it involves several acidic or basic compounds.

The results enable to determine the kinetic constant of the reaction between the hydrosulfide anion ( $\left.\mathrm{HS}^{-}\right)$and the hypochlorous acid $(\mathrm{ClOH}): \mathrm{k}_{35}=1.210^{9} \mathrm{~L} \mathrm{~mol}^{-1} \mathrm{~s}^{-1}$ at $298 \mathrm{~K}$. This reaction is prevalent in the $\mathrm{pH}$ range 6-12 even if $\mathrm{ClO}^{-}$is predominant over $\mathrm{ClOH}$ at $\mathrm{pH}>$ 7.54. The potential reactions between the hypochlorous acid and the conjugated acid $\left(\mathrm{H}_{2} \mathrm{~S}\right)$ and base $\left(\mathrm{S}^{2-}\right)$ are unlikely. Moreover, the reaction between the hypochlorite anion $\left(\mathrm{ClO}^{-}\right)$ and $\mathrm{HS}^{-}$was confirmed as negligible. However, we cannot confirm that the reaction between $\mathrm{ClOH}$ and $\mathrm{S}^{2-}$ is unlikely at $\mathrm{pH}>12$.

Numerical simulations focused on both sulfite and sulfide oxidations demonstrated that oxidation rates are limited by the various acid base reactions whose kinetic rates are not sufficient to maintain the acid base pairs equilibria. Consequently, in the range $\mathrm{pH}=6$ $\mathrm{pH}=10$, the true kinetic rate should be lower than the kinetic rate determined assuming that acid and base equilibriums are maintained during the oxidation.

The results of these simulations enable to correlate the result of the competitive method. Additionally to sulfide kinetics investigation, the results allowed to affirm that the potential reaction between $\mathrm{HSO}_{3}{ }^{-}$and $\mathrm{ClOH}$ is unlikely at least at $\mathrm{pH}>6$. 
526 the possibility of working at such $\mathrm{pH}$ in chemical scrubbing to avoid $\mathrm{Cl}_{2}$ desorption in the 527 treated gas.

528 In future, the influence of the sulfide oxidation kinetic rates in chemical scrubbing will 529 be assessed to develop a tool for scrubbers design as well as to understand deeper the 530 mechanism involved. 

Raton.

Beltrán, F.J., 2004. Ozone reaction kinetics for water and wastewater systems. CRC Press, Boca

Biard, P.-F., Couvert, A., Renner, C., Levasseur, J.-P., 2010. Wet scrubbing intensification applied to hydrogen sulphide removal in waste water treatment plant. The Canadian Journal of Chemical Engineering 88, 682-687.

Biard, P.-F., Couvert, A., Renner, C., Levasseur, J.-P., 2011. Intensification of VOC gas-liquid mass transfer in a compact scrubber using the peroxone process: kinetic study and hydroxyl radical tracking. Chemosphere.

Biard, P.-F., Couvert, A., Renner, C., Zozor, P., Bassivière, S., Levasseur, J.-P., 2009. Hydrogen sulphide removal in waste water treatment plant by compact oxidative scrubbing in Aquilair Plus ${ }^{\mathrm{TM}}$ process. Water Practice and Technology 4, doi:10.2166/wpt.2009.2023.

Bonnin, C., 1991. Les sources de nuisances olfactives dans les stations de traitement des eaux usées résiduaires, et leur traitement par lavage à l'eau chlorée en milieu basique, Ecole Nationale Supérieure de Chimie de Rennes. Université de Rennes I, Rennes, p. 191.

Busca, G., Chiara, P., 2003. Technologies for the abatement of sulphide compounds from gaseous streams: a comparative overview. Journal of Loss Prevention in the Process Industries 16, 363-371.

Cadena, F., Peter, R., 1988. Evaluation of chemical oxidizers for hydrogen sulfide control. Journal- Water Pollution Control Federation 60, 1259-1263.

Chen, L., Huang, J., Yang, C.-L., 2001. Absorption of $\mathrm{H}_{2} \mathrm{~S}$ in $\mathrm{NaOCl}$ caustic aqueous solution. Environmental Progress 20, 175-181.

Choppin, A.R., Faulkenberry, L.C., 1937. The Oxidation of Aqueous Sulfide Solutions by Hypochlorites. Journal of the American Chemical Society 59, 2203-2207.

Couvert, A., Charron, I., Laplanche, A., Renner, C., Patria, L., Requieme, B., 2006. Treatment of odorous sulphur compounds by chemical scrubbing with hydrogen peroxide - Application to a laboratory plant. Chemical Engineering Science 61, 7240-7248.

de Carvalho, L.M., Schwedt, G., 2000. Sulfur speciation by capillary zone electrophoresis: conditions for sulfite stabilization and determination in the presence of sulfate, thiosulfate and peroxodisulfate. Fresenius' journal of analytical chemistry 368, 208-213.

Deborde, M., Von Gunten, U., 2008. Reactions of chlorine with inorganic and organic compounds during water treatment - Kinetics and mechanisms: A critical review. Water Research 42 , 13-51.

Doré, M., 1989. Chimie des oxydants et traitement des eaux, Paris.

Eigen, M., 1964. Proton transfer, acid-base catalysis, and enzymatic hydrolysis. Part I: elementary processes. Angewandte Chemie International Edition in English 3, 1-19.

Féliers, C., Patria, L., Morvan, J., Laplanche, A., 2001. Kinetics of oxidation of odorous sulfur compounds in aqueous alkaline solution with $\mathrm{H}_{2} \mathrm{O}_{2}$. Environmental technology 22, 1137-1146.

Fogelman, K.D., Walker, D.M., Margerum, D.W., 1989. Nonmetal redox kinetics: hypochlorite and hypochlorous acid reactions with sulfite. Inorganic Chemistry 28, 986-993.

Fogo, J.K., Popowsky, M., 1949. Spectrophotometric determination of hydrogen sulfide. Analytical Chemistry 21, 732-734.

Giggenbach, W., 1971. Optical spectra of highly alkaline sulfide solutions and the second dissociation constant of hydrogen sulfide. Inorganic Chemistry 10, 1333-1338.

Gostelow, P., Parsons, S.A., Stuetz, R.M., 2001. Odour measurements for sewage treatment works. Water Research 35, 579-597.

Hoigne, J., Bader, H., 1983. Rate constants of reactions of ozone with organic and inorganic compounds in water- I. Non-dissociating organic compounds. Water Research 17, 173-183. 
Kangas, J., Jäppinen, P., Savolainen, H., 1984. Exposure to Hydrogen Sulfide, Mercaptans and
Sulfur Dioxide in Pulp Industry. American Industrial Hygiene Association Journal 45, 787-790.

Kerc, A., Olmez, S.S., 2010. Ozonation of Odorous Air in Wastewater Treatment Plants. Ozone Science \& Engineering 32, 199 - 203.

Kohl, A.L., Nielsen, R., 1997. Gas purification. Gulf Professional Publishing.

Licht, S., Forouzan, F., Longo, K., 1990. Differential densometric analysis of equilibria in highly concentrated media: determination of the aqueous second acid dissociation constant of $\mathrm{H} 2 \mathrm{~S}$. Analytical Chemistry 62, 1356-1360.

Meyer, B., Ward, K., Koshlap, K., Peter, L., 1983. Second dissociation constant of hydrogen sulfide. Inorganic Chemistry 22, 2345-2346.

Migdisov, A.A., Williams-Jones, A.E., Lakshtanov, L.Z., Alekhin, Y.V., 2002. Estimates of the second dissociation constant of $\mathrm{H} 2 \mathrm{~S}$ from the surface sulfidation of crystalline sulfur. Geochimica et Cosmochimica Acta 66, 1713-1725.

Rappert, S., Müller, R., 2005. Odor compounds in waste gas emissions from agricultural operations and food industries. Waste Management 25, 887-907.

Reese, B.K., Finneran, D.W., Mills, H.J., Zhu, M.-X., Morse, J.W., 2011. Examination and refinement of the determination of aqueous hydrogen sulfide by the methylene blue method. Aquatic Geochemistry 17, 567-582.

Rhee, J.S., Dasgupta, P.K., 1985. The second dissociation constant of sulfur dioxide.water. The Journal of Physical Chemistry 89, 1799-1804.

Roustan, M., 2003. Transferts gaz-liquide dans les procédés de traitement des eaux et des effluents gazeux. Lavoisier, Paris.

Stephens, H.P., Cobble, J.W., 1971. Thermodynamic properties of the aqueous sulfide and bisulfide ions and the second ionization constant of hydrogen sulfide over extended temperatures. Inorganic Chemistry 10, 619-625.

Vilmain, J.-B., Courousse, V., Biard, P.-F., Azizi, M., Couvert, A., 2014. Kinetic study of hydrogen sulfide absorption in aqueous chlorine solution. Chemical Engineering Research and Design 92, 191204.

Wang, T.X., Margerum, D.W., 1994. Kinetics of reversible chlorine hydrolysis: Temperature dependence and general-acid/base-assisted mechanisms. Inorganic Chemistry 33, 1050-1055. 


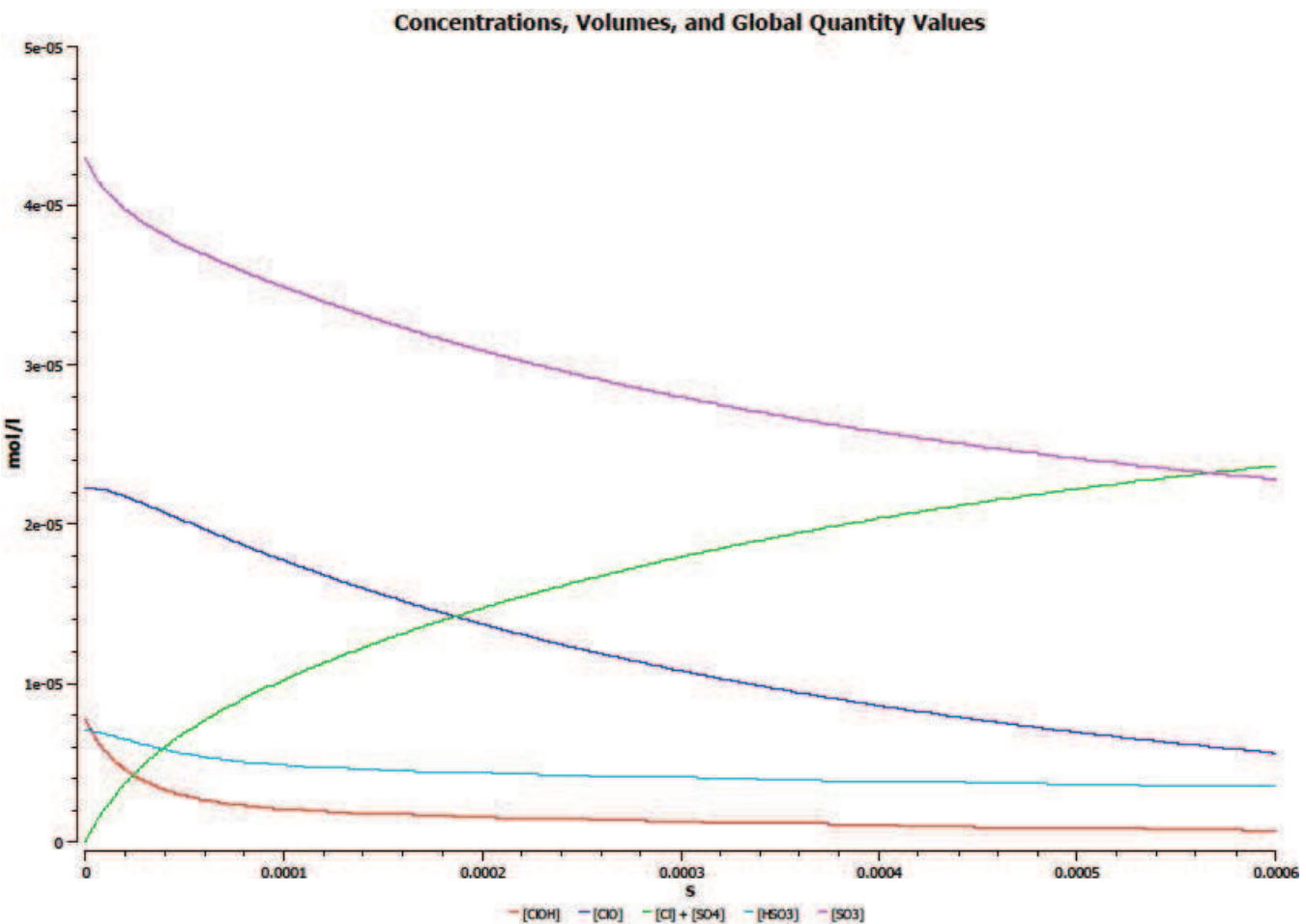




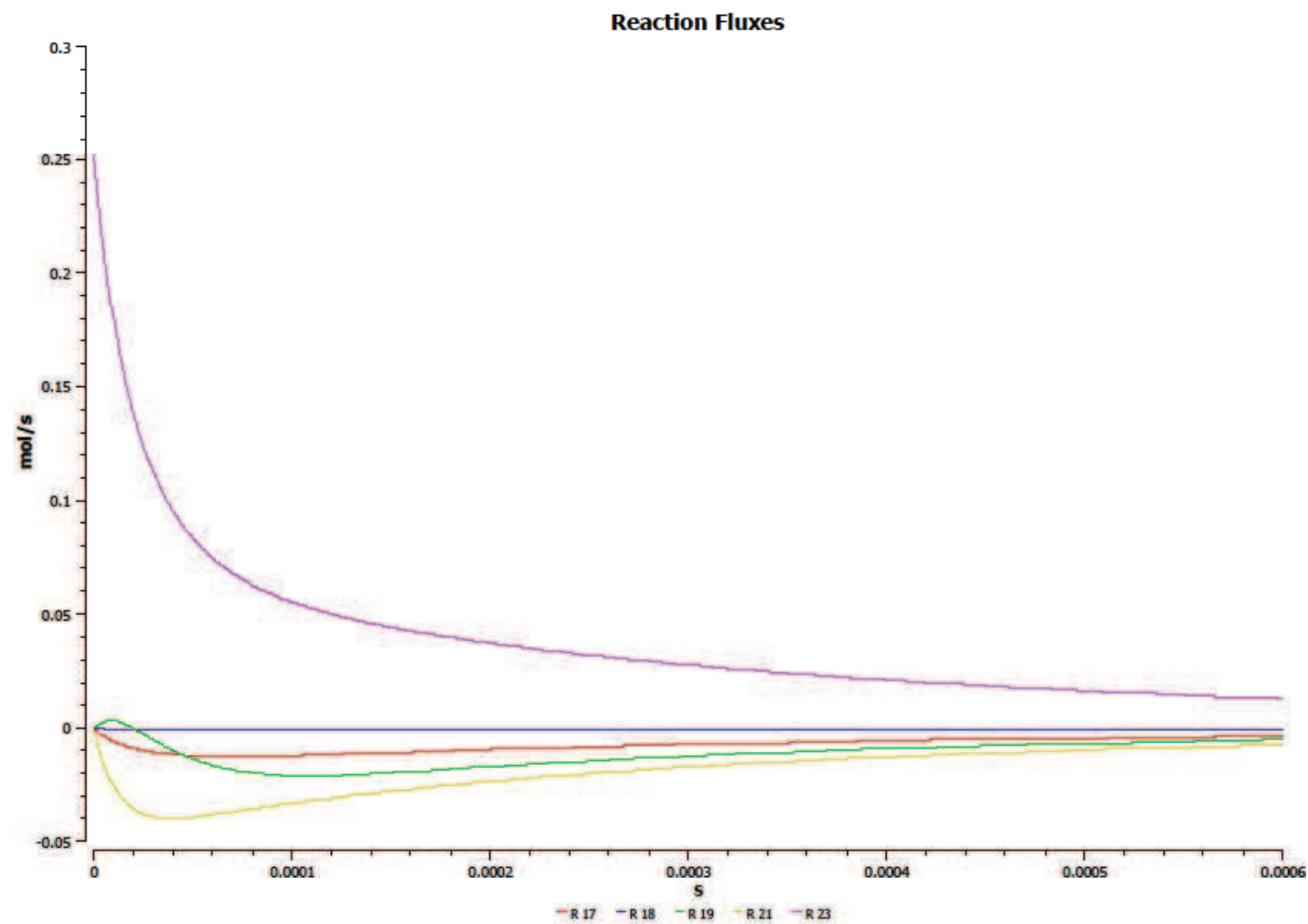

616 which simulates the initial concentrations used with the competitive kinetics method. 


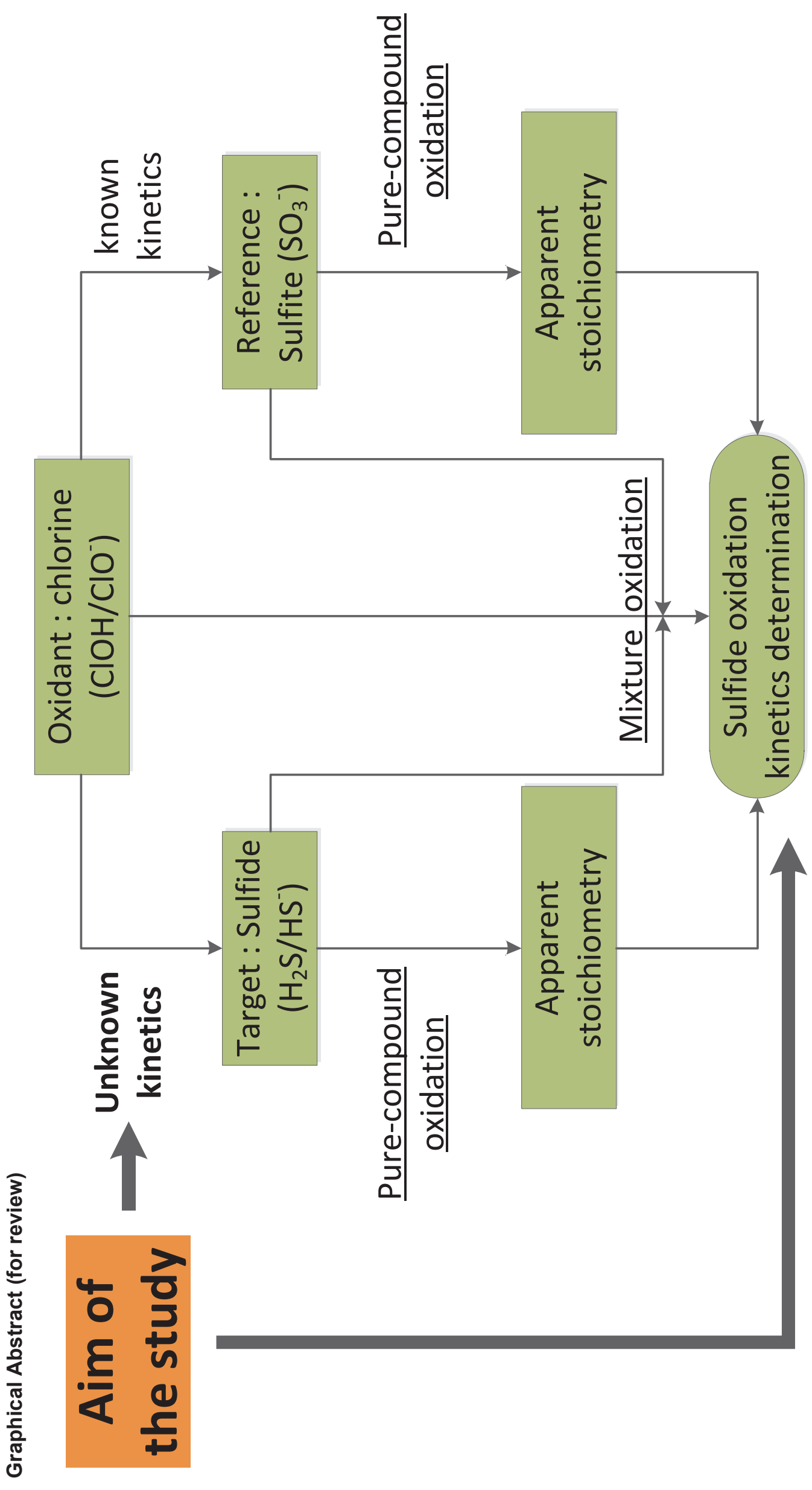


Sulfide chlorination kinetics was studied using the competitive method

Sulfite was selected as the reference compound

The sulfide oxidation in the $\mathrm{pH}$ range $6-12$ is mainly due to $\mathrm{HS}^{-}$oxidation by $\mathrm{ClOH}$

Kinetic constants between $\mathrm{ClOH}$ and $\mathrm{HS}^{-}$is evaluated at $1.2 \times 10^{9} \mathrm{~L} \mathrm{~mol}^{-1} \mathrm{~s}^{-1}$

Numerical resolutions are performed to check the reliability 


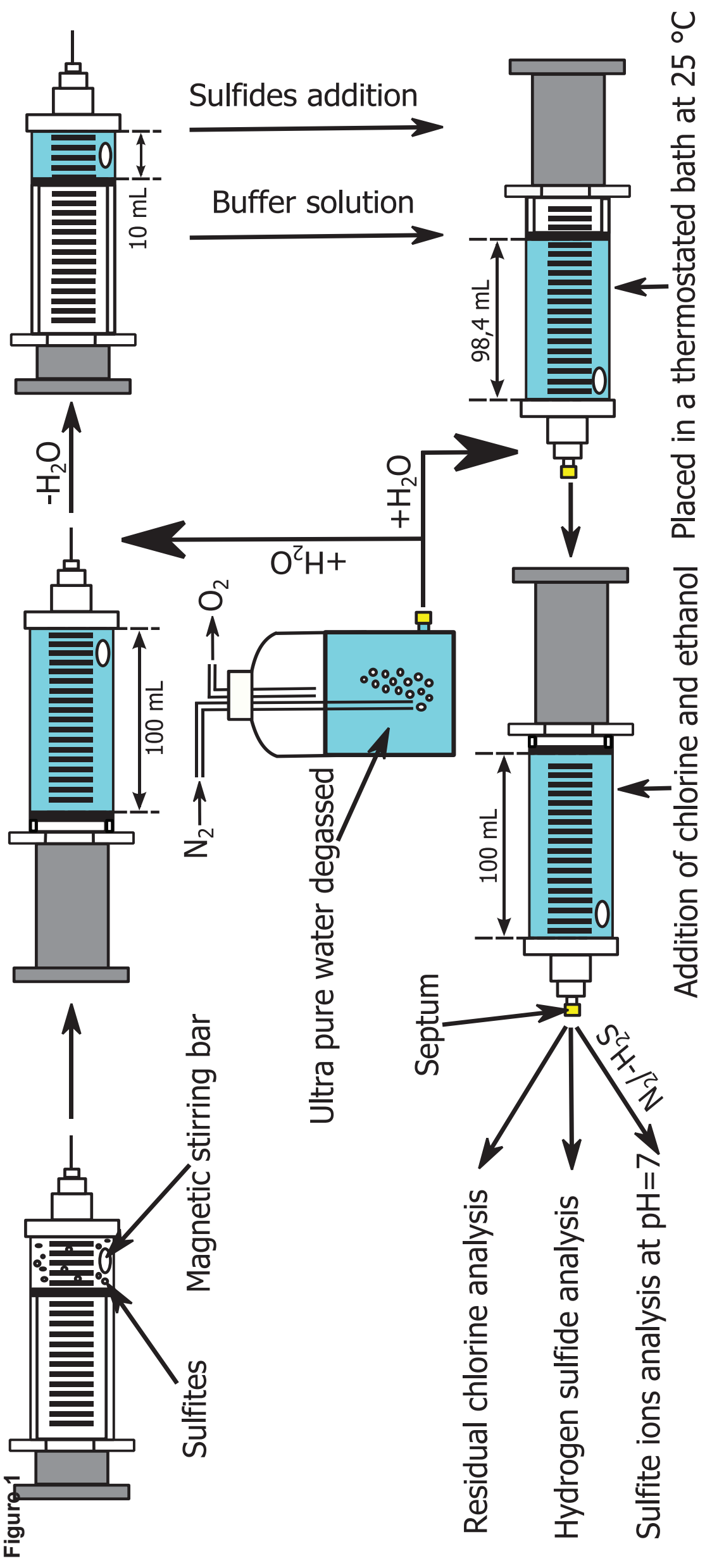




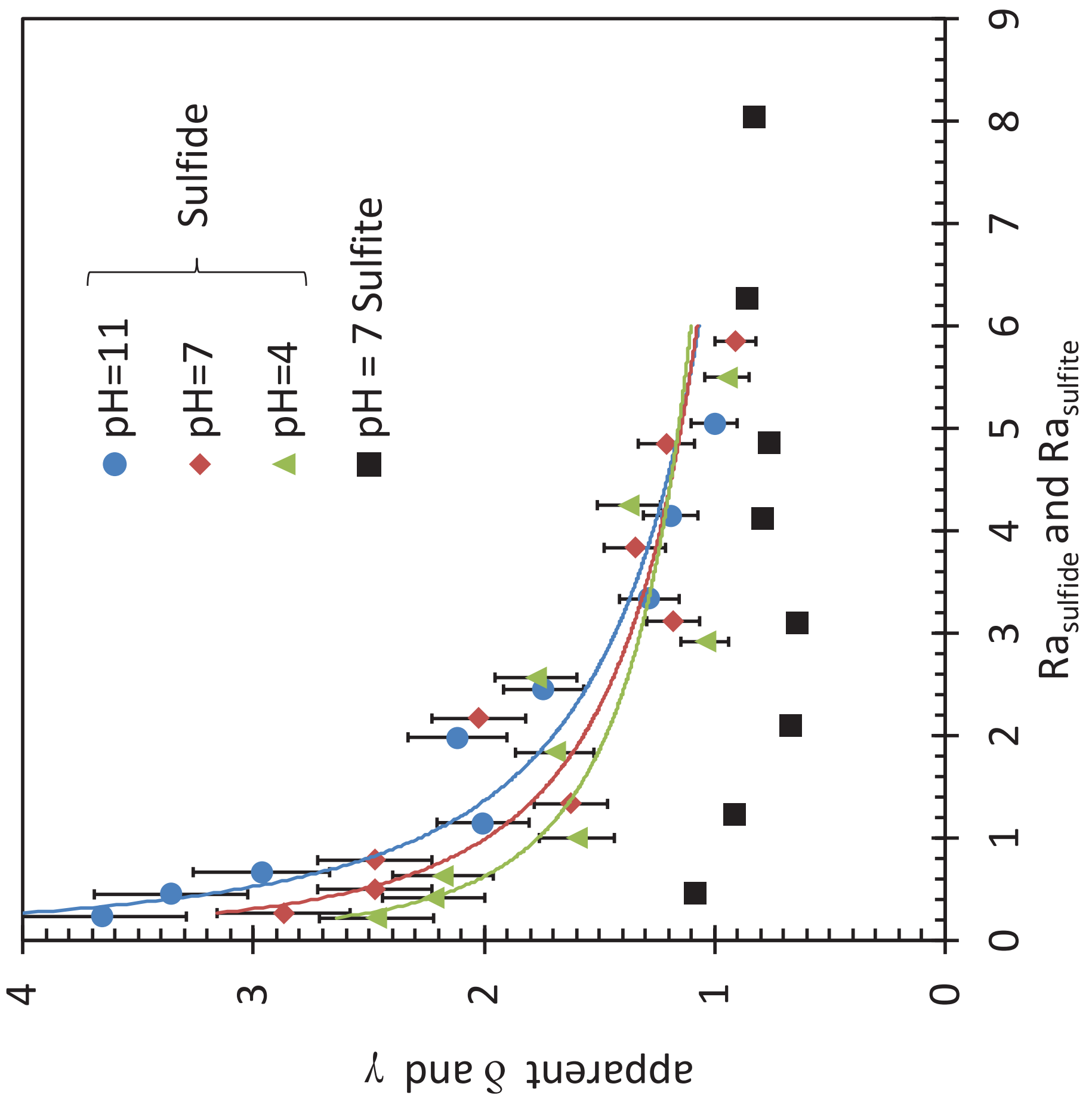

ำ 


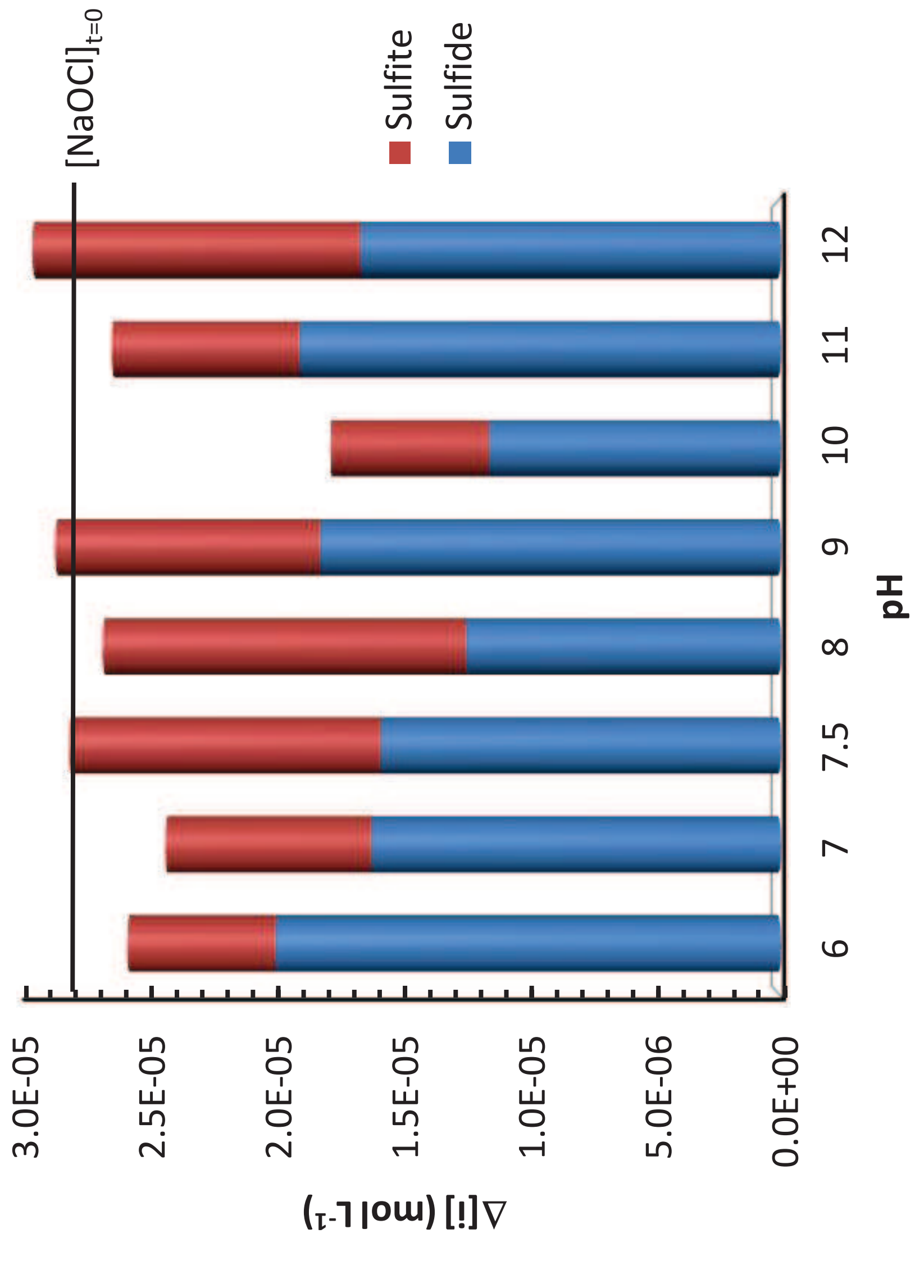




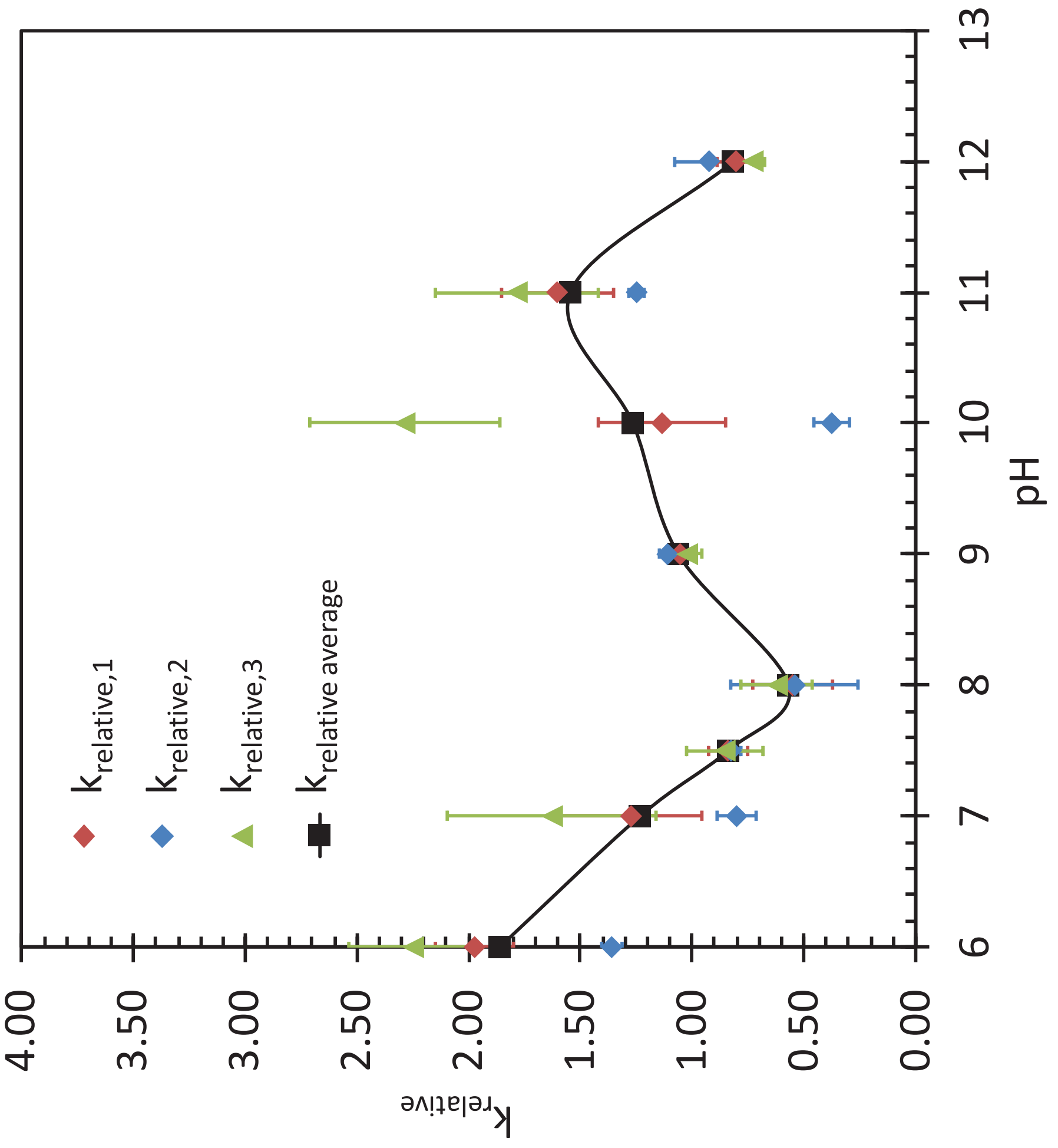

$\forall$
일
믄 


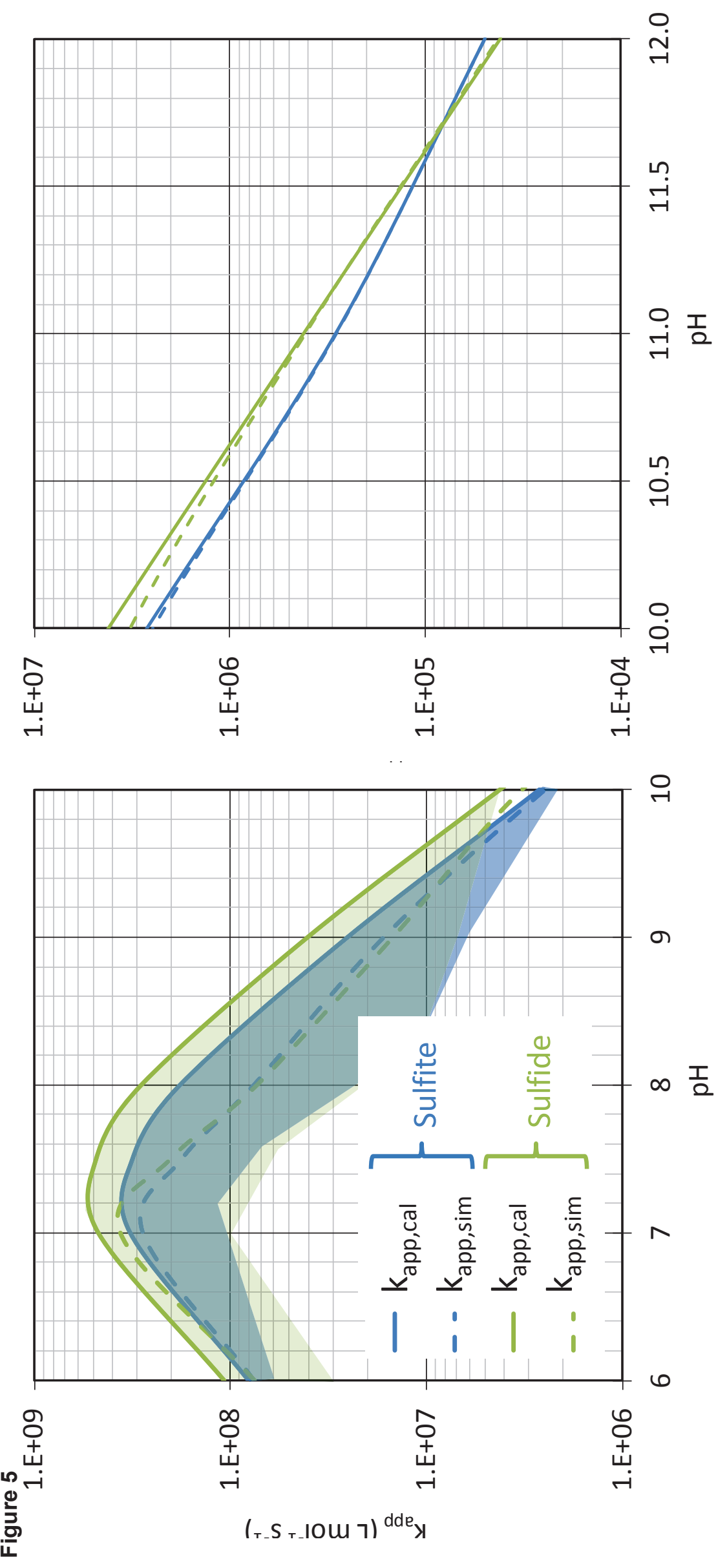




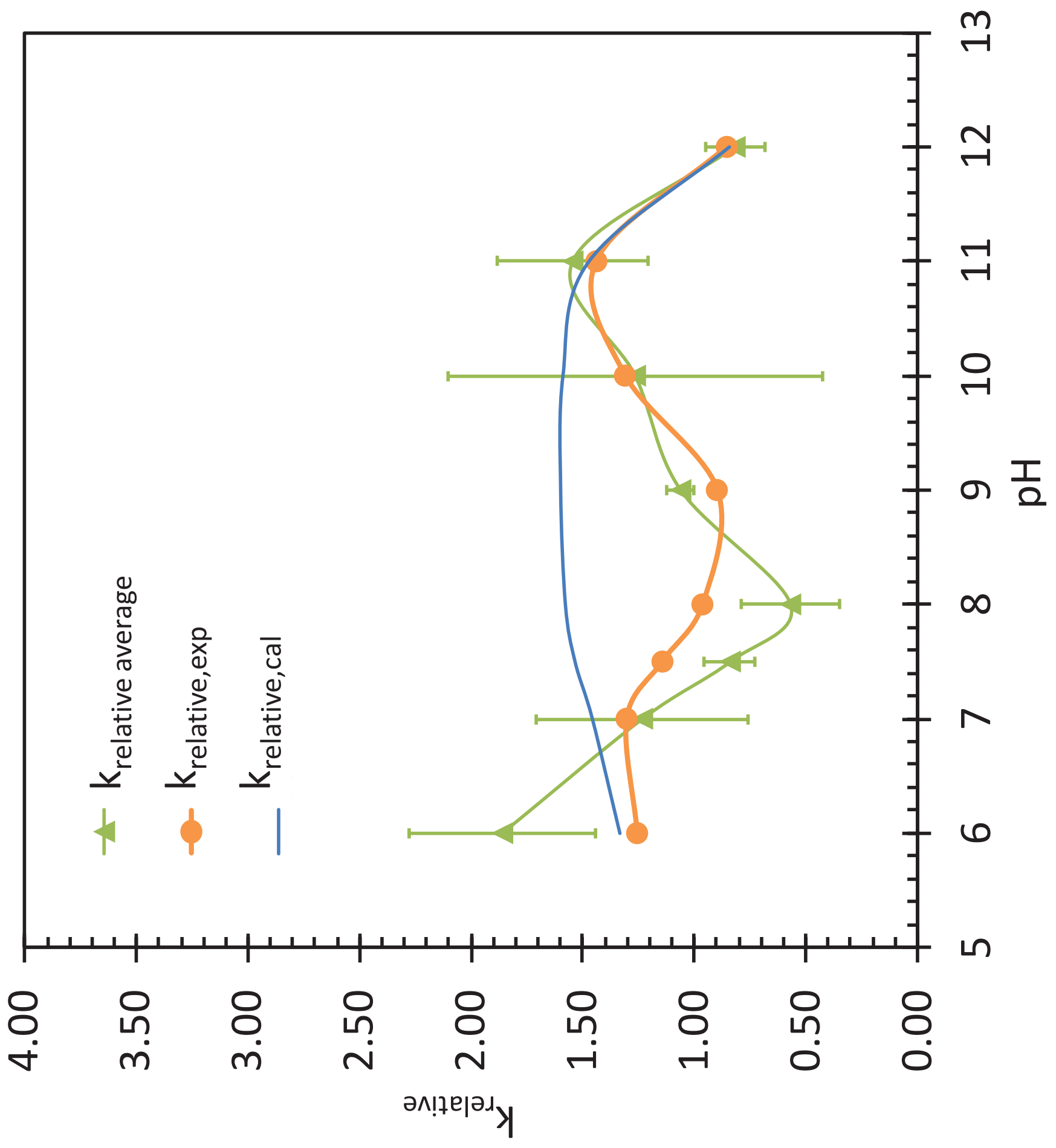


Table 1: Reactions involved in the sulfite oxidation mechanism. $K_{i}$ (equilibrium constants) and $k_{i}$ (kinetic constants) are reported at $298 \mathrm{k}$.

\begin{tabular}{|c|c|c|c|}
\hline Reaction & $\begin{array}{l}\text { Eq } \\
\text { (i) }\end{array}$ & $\mathbf{K}_{\mathbf{i}}$ & $\mathbf{k}_{\mathbf{i}}$ \\
\hline $\mathrm{ClOH}+\mathrm{HO}^{-} \frac{\mathrm{k}_{12}}{\mathrm{k}_{-17}} \mathrm{ClO}^{-}+\mathrm{H}_{2} \mathrm{O}$ & (17) & ${ }^{1} 10^{\mathrm{pKW}-\mathrm{pk}} \mathrm{a}_{\mathrm{a}, 4}=2.88 \times 10^{6}$ & $\begin{aligned}{ }^{2} \mathrm{k}_{17} & =3 \times 10^{9} \mathrm{~L} \mathrm{~mol}^{-1} \mathrm{~s}^{-1} \\
\mathrm{~K}_{-17} & =1.0 \times 10^{3} \mathrm{~s}^{-1}\end{aligned}$ \\
\hline$\frac{\mathrm{k}_{18}}{\mathrm{k}_{-18}} \mathrm{ClO}^{-}+\mathrm{H}^{+}$ & (18) & $10^{-p K_{a}, 4}=2.88 \times 10^{-8}$ & $\begin{array}{c}\mathrm{k}_{18}=288 \mathrm{~s}^{-1} \\
{ }^{3} \mathrm{k}_{-18}=10^{10} \mathrm{~L} \mathrm{~mol}^{-1} \mathrm{~s}^{-1}\end{array}$ \\
\hline $\mathrm{HSO}_{3}{ }^{-}+\mathrm{HO}-\frac{\mathrm{k}_{12}}{\mathrm{k}_{-19}} \mathrm{SO}_{3}{ }^{2-}+\mathrm{H}_{2} \mathrm{O}$ & (19) & $10^{\mathrm{pKW}-\mathrm{pK} \mathrm{K}_{\mathrm{a}, 5}}=1.23 \times 10^{7}$ & $\begin{array}{c}{ }^{b} k_{19}=2.5 \times 10^{10} \mathrm{~L} \mathrm{~mol}^{-1} \mathrm{~s}^{-1} \\
\mathrm{~K}_{-19}=2.3 \times 10^{3} \mathrm{~s}^{-1}\end{array}$ \\
\hline $\mathrm{HSO}_{3}{ }^{-} \quad \frac{\mathrm{k}_{2 \mathrm{Q}}}{\mathrm{k}_{-2 \mathrm{O}}} \mathrm{SO}_{3}{ }^{2-}+\mathrm{H}^{+}$ & (20) & $10^{-p K_{a, 5}}=1.23 \times 10^{-7}$ & $\begin{array}{c}k_{20}=9.2 \times 10^{3} \mathrm{~s}^{-1} \\
-20=7.5 \times 10^{10} \mathrm{~L} \mathrm{~mol}^{-1} \mathrm{~s}^{-1}\end{array}$ \\
\hline $\mathrm{ClOH}+\mathrm{SO}_{3}{ }^{2-}=\frac{\mathrm{k}_{21}}{\mathrm{k}_{-21}} \mathrm{ClO}^{-}+\mathrm{HSO}_{3}^{-}$ & (21) & $10^{p K_{a, 5}-p K_{a, 4}}=0.23$ & $\begin{aligned}{ }^{b} k_{21} & =3 \times 10^{8} \mathrm{~L} \mathrm{~mol}^{-1} \mathrm{~s}^{-1} \\
\mathrm{k}_{-21} & =1.28 \times 10^{9} \mathrm{~L} \mathrm{~mol}^{-1} \mathrm{~s}^{-1}\end{aligned}$ \\
\hline $\mathrm{ClO}^{-}+\mathrm{SO}_{3}{ }^{2-} \stackrel{\mathrm{k}_{22}}{\longrightarrow} \mathrm{SO}_{4}^{2-}+\mathrm{Cl}^{-}$ & (22) & & ${ }^{c} \mathrm{k}_{22}=2.3 \times 10^{4} \mathrm{~L} \mathrm{~mol}^{-1} \mathrm{~s}^{-1}$ \\
\hline $\mathrm{ClOH}+\mathrm{SO}_{3}{ }^{2-} \stackrel{\mathrm{K}_{23}}{\longrightarrow} \mathrm{SO}_{4}{ }^{2-}+\mathrm{Cl}^{-}+\mathrm{H}^{+}$ & (23) & & ${ }^{c} \mathrm{k}_{23}=7.6 \times 10^{8} \mathrm{Lmol}^{-1} \mathrm{~s}^{-1}$ \\
\hline $\mathrm{ClOH}+\mathrm{HSO}_{3}{ }^{-} \stackrel{\mathrm{k}_{24}}{\longrightarrow} \mathrm{SO}_{4}{ }^{2-}+\mathrm{Cl}^{-}+2 \mathrm{H}^{+}$ & (24) & & $\begin{array}{l}\text { Assumed to be negligible at } \\
\qquad \mathrm{pH}>6-7\end{array}$ \\
\hline
\end{tabular}

\footnotetext{
${ }^{1} \mathrm{~K}_{\mathrm{w}}$ is the water dissociation constant $=10^{-14}$ at $298 \mathrm{~K}$.

2 (Eigen, 1964)

${ }^{3}$ (Fogelman et al., 1988)
} 


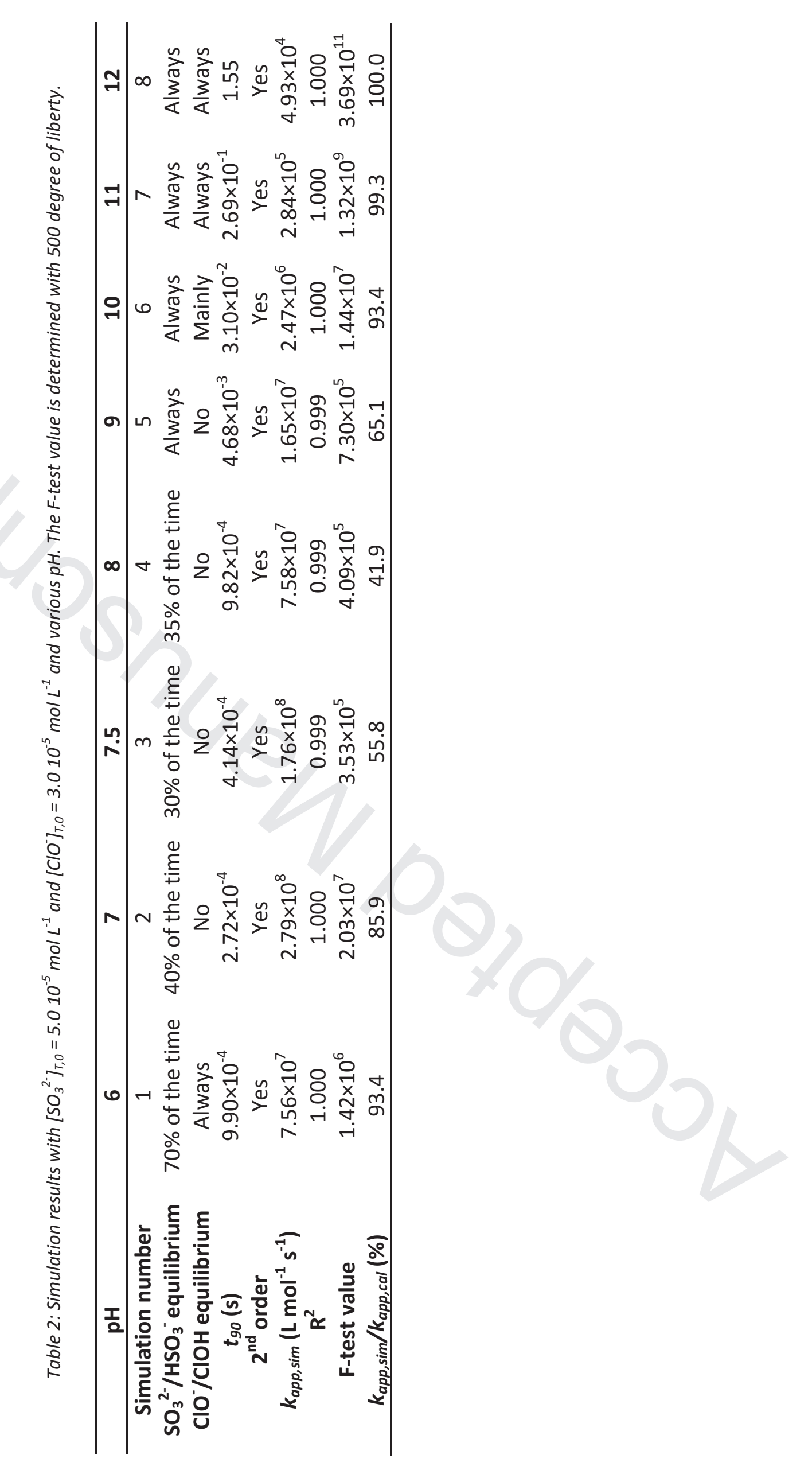


Table 3: Simulation results at $\mathrm{pH}=8$ and various chlorine and sulfite concentrations keeping a constant ratio. The F-test value is determined with 500 degree of liberty.

\begin{tabular}{|c|c|c|c|c|}
\hline $\begin{array}{c}{\left[\mathrm{SO}_{3}{ }^{2-}\right]_{\mathrm{T}, 0}\left(\mathrm{~mol} \mathrm{~L}^{-1}\right)} \\
{\left[\mathrm{ClO}^{-}\right]_{\mathrm{T}, 0}\left(\mathrm{~mol} \mathrm{~L}^{-1}\right)}\end{array}$ & $\begin{array}{l}5.0 \times 10^{-6} \\
3.0 \times 10^{-6}\end{array}$ & $\begin{array}{l}5.0 \times 10^{-5} \\
3.0 \times 10^{-5}\end{array}$ & $\begin{array}{l}5.0 \times 10^{-4} \\
3.0 \times 10^{-4}\end{array}$ & $\begin{array}{l}5.0 \times 10^{-3} \\
3.0 \times 10^{-3}\end{array}$ \\
\hline Simulation number & 9 & 4 & 10 & 11 \\
\hline $\mathrm{SO}_{3}{ }^{2-} / \mathrm{HSO}_{3}^{-}$equilibrium & Always & $35 \%$ of the time & No & No \\
\hline $\mathrm{ClO}^{-} / \mathrm{ClOH}$ equilibrium & No & No & No & No \\
\hline$t_{90}(s)$ & $5.48 \times 10^{-3}$ & $9.82 \times 10^{-4}$ & $2.66 \times 10^{-4}$ & $1.75 \times 10^{-4}$ \\
\hline $2^{\text {nd }}$ order & Yes & Yes & Yes & Almost \\
\hline$k_{a p p, s i m}\left(\mathrm{~L} \mathrm{~mol}^{-1} \mathrm{~s}^{-1}\right)$ & $1.38 \times 10^{8}$ & $7.58 \times 10^{7}$ & $2.7 \times 10^{7}$ & $3.96 \times 10^{6}$ \\
\hline$R^{2}$ & 1.000 & 0.999 & 0.980 & 0.950 \\
\hline F-test value & $1.69 \times 10^{6}$ & $4.09 \times 10^{5}$ & $3.02 \times 10^{4}$ & $1.17 \times 10^{4}$ \\
\hline$k_{a p p, s i m} / k_{a p p, c a l}(\%)$ & 76.3 & 41.9 & 14.9 & 2.2 \\
\hline
\end{tabular}


Table 4: Simulation results at $\mathrm{pH}=8$ and various chlorine and sulfite concentrations. The F-test value is determined with 500 degree of liberty.

\begin{tabular}{|c|c|c|c|c|c|}
\hline $\begin{array}{c}{\left[\mathrm{SO}_{3}{ }^{2-}\right]_{\mathrm{T}, 0}\left(\mathrm{~mol} \mathrm{~L}^{-1}\right)} \\
{\left[\mathrm{ClO}^{-}\right]_{\mathrm{T}, 0}\left(\mathrm{~mol} \mathrm{~L}^{-1}\right)}\end{array}$ & $\begin{array}{l}5.0 \times 10^{-5} \\
3.0 \times 10^{-5}\end{array}$ & $\begin{array}{l}5.0 \times 10^{-5} \\
5.0 \times 10^{-5}\end{array}$ & $\begin{array}{l}3.0 \times 10^{-5} \\
5.0 \times 10^{-5}\end{array}$ & $\begin{array}{l}5.0 \times 10^{-3} \\
3.0 \times 10^{-5}\end{array}$ & $\begin{array}{l}5.0 \times 10^{-5} \\
3.0 \times 10^{-3}\end{array}$ \\
\hline Simulation number & 4 & 12 & 13 & 14 & 15 \\
\hline $\mathrm{SO}_{3}{ }^{2-} / \mathrm{HSO}_{3}{ }^{-}$equilibrium & $\begin{array}{l}35 \% \text { of the } \\
\text { time }\end{array}$ & $\begin{array}{l}40 \% \text { of the } \\
\text { time }\end{array}$ & $\begin{array}{l}\text { Almost } \\
\text { never }\end{array}$ & Always & $\begin{array}{l}\text { almost } \\
\text { never }\end{array}$ \\
\hline $\mathrm{ClO}^{-} / \mathrm{ClOH}$ equilibrium & No & No & No & No & Always \\
\hline$t_{90}(\mathrm{~s})$ & $9.82 \times 10^{-4}$ & $1.90 \times 10^{-3}$ & $7.52 \times 10^{-4}$ & $\begin{array}{c}6.68 \times 10^{-} \\
6\end{array}$ & $4.46 \times 10^{-6}$ \\
\hline $2^{\text {nd }}$ order & Yes & Yes & Yes & Yes & Almost \\
\hline$k_{a p p, s i m}\left(\mathrm{~L} \mathrm{~mol}^{-1} \mathrm{~s}^{-1}\right)$ & $7.58 \times 10^{7}$ & $9.50 \times 10^{7}$ & $9.76 \times 10^{7}$ & $6.61 \times 10^{7}$ & $1.73 \times 10^{8}$ \\
\hline $\mathbf{R}^{2}$ & 0.999 & 0.975 & 0.993 & 0.985 & 0.949 \\
\hline F-test value & $4.09 \times 10^{5}$ & $6.57 \times 10^{4}$ & $1.22 \times 10^{5}$ & $7.05 \times 10^{5}$ & $2.51 \times 10^{7}$ \\
\hline $\boldsymbol{k}_{a p p, s i m} / \boldsymbol{k}_{a p p, c a l}(\%)$ & 41.9 & 52.5 & 53.9 & 36.5 & 95.8 \\
\hline
\end{tabular}


Table 5: Reactions involved in the sulfide oxidation mechanism. $K_{i}$ (equilibrium constants) and $k_{i}$ (kinetic constants) are reported at $298 \mathrm{~K}$. S can be further oxidized. We consider it as negligible since we used $R a_{\text {sulfide }}$ such as elemental sulfur oxidation would remain marginal.

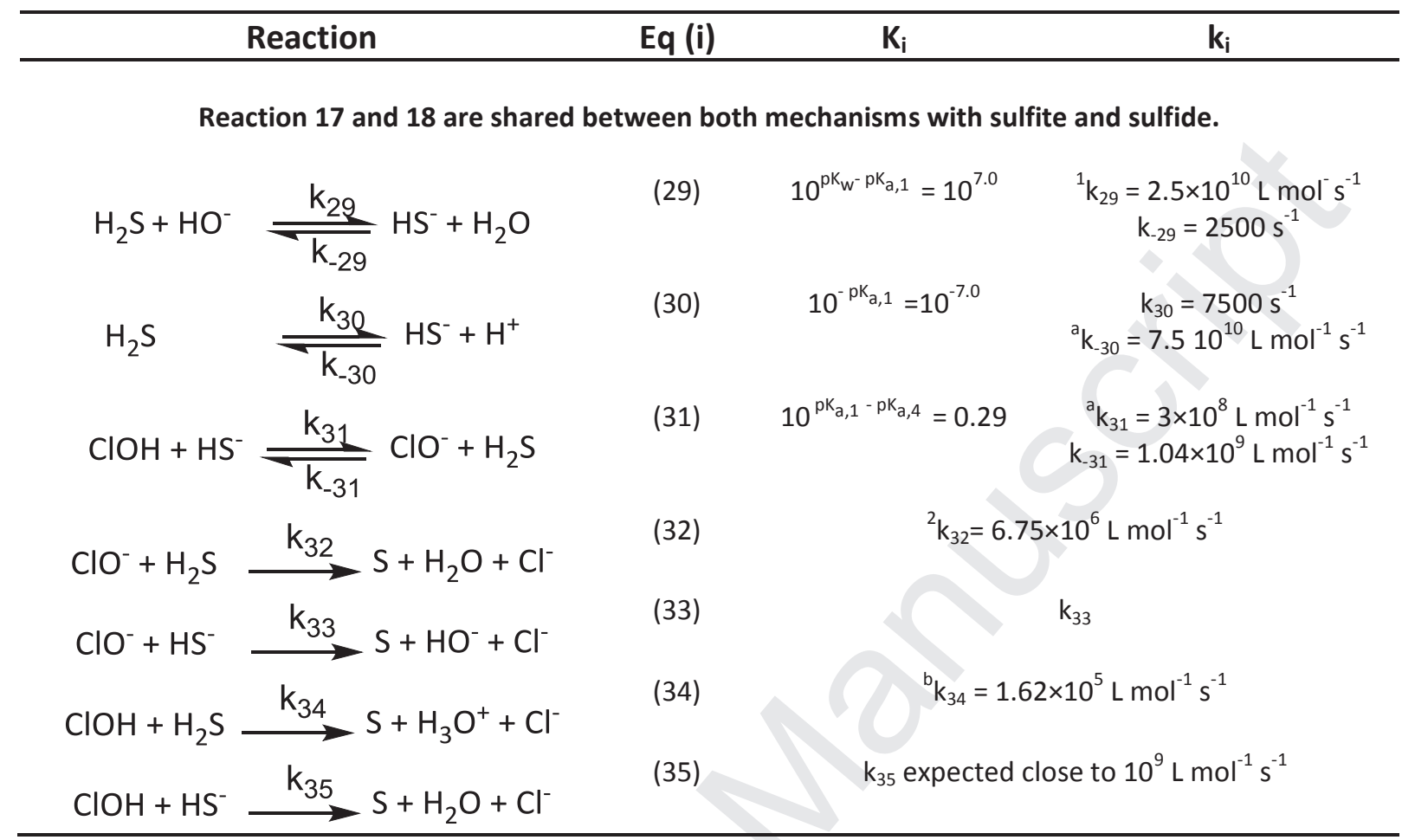

${ }^{1}$ (Eigen, 1964)

2 (Vilmain et al., 2014) 
Table 6: Numerical resolution results for $k_{35}$ value determination.

\begin{tabular}{ccccc}
\hline $\mathrm{pH}$ & \multicolumn{1}{c}{$\mathbf{1 1}$} & \multicolumn{2}{c}{$\mathbf{1 2}$} \\
\hline $\mathbf{k}_{\text {relative }}$ & \multicolumn{2}{c}{1.55} & \multicolumn{2}{c}{0.82} \\
$\mathbf{k}_{\text {app,exp }}\left(\mathrm{L} \mathrm{mol}^{-1} \mathbf{s}^{-1}\right)$ & \multicolumn{2}{c}{$4.4 \times 10^{5}$} & \multicolumn{2}{c}{$4.0 \times 10^{4}$} \\
\hline $\mathbf{k}_{33}$ value $\left(\mathrm{L} \mathrm{mol}^{-1} \mathbf{s}^{-1}\right)$ & 0 & $10^{4}$ & 0 & $10^{4}$ \\
$\mathbf{k}_{35}$ value $\left(\mathrm{L} \mathrm{mol}^{-1} \mathbf{s}^{-1}\right)$ & $1.23 \times 10^{9}$ & $1.05 \times 10^{9}$ & $1.23 \times 10^{9}$ & $1.05 \times 10^{9}$ \\
$\boldsymbol{k}_{\text {app,cal }}\left(\mathrm{L} \mathrm{mol}^{-1} \mathbf{s}^{-1}\right)$ & $4.2 \times 10^{5}$ & $3.7 \times 10^{5}$ & $4.2 \times 10^{4}$ & $4.6 \times 10^{5}$ \\
$\boldsymbol{F}_{\boldsymbol{i}}(\%)$ & 0.23 & 2.51 & 0.19 & 2.09 \\
Error (\%) & 5 & 16 & 4 & 14 \\
$\mathbf{k}_{33} / \boldsymbol{k}_{\text {app,cal }}(\%)$ & 0 & 2.7 & 0 & 21.6 \\
\hline
\end{tabular}




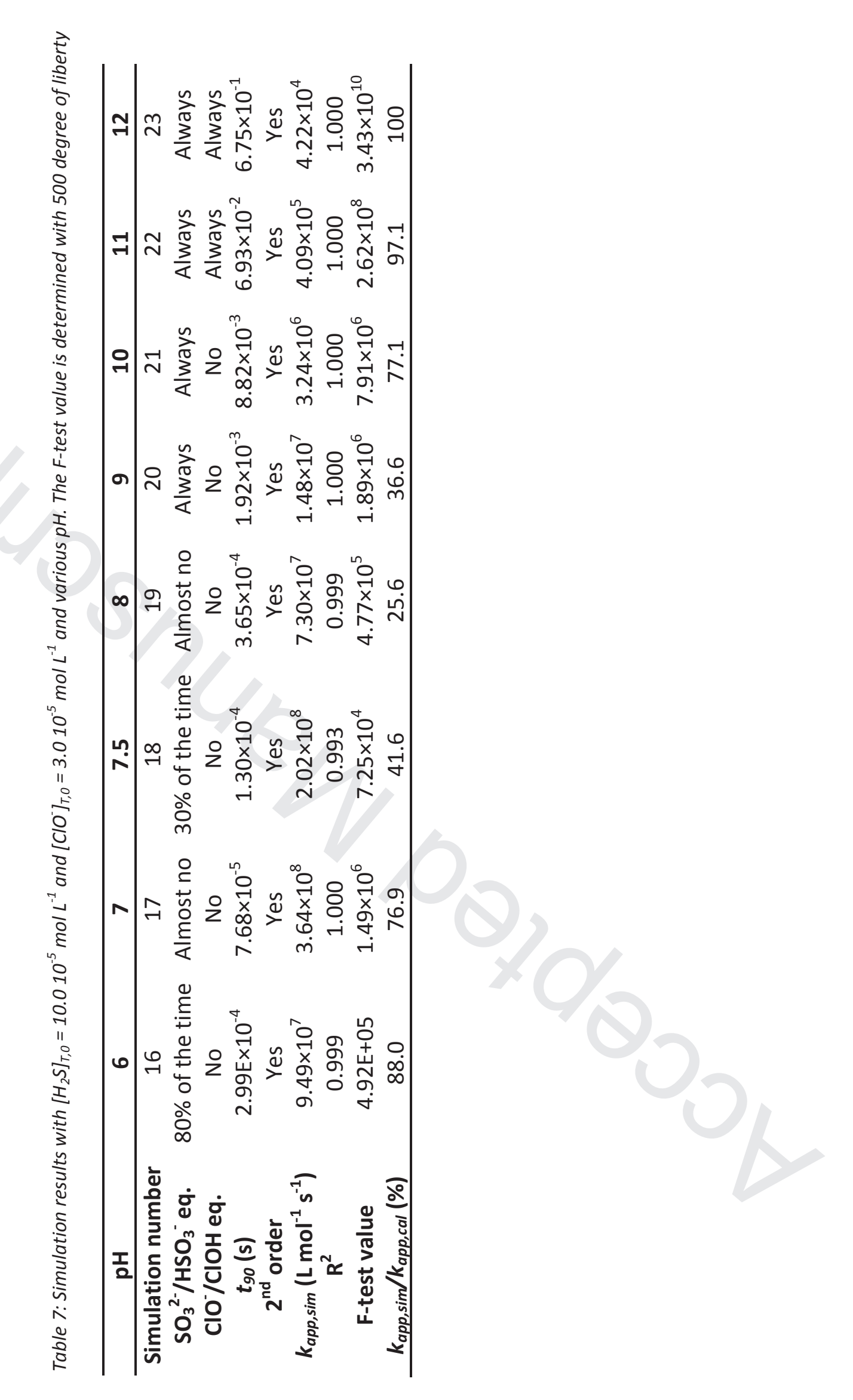


Table 8: Simulation results with underestimated and overestimated kinetic constants of acid-base reactions. The operating conditions are those of simulations \#1 and \#16.

\begin{tabular}{|c|c|c|c|c|}
\hline $\begin{array}{l}\text { Simulation } \\
\text { number }\end{array}$ & $\begin{array}{c}24\left(k_{i}\right. \\
\text { understimations } \\
\text { for sulfite) }\end{array}$ & $\begin{array}{c}25 \text { ( } \mathbf{k}_{\mathbf{i}} \\
\text { overestimations } \\
\text { for sulfite) }\end{array}$ & $\begin{array}{c}26\left(k_{i}\right. \\
\text { underestimations } \\
\text { for sulfide) }\end{array}$ & $\begin{array}{c}27\left(k_{i}\right. \\
\text { overestimations } \\
\text { for sulfide) }\end{array}$ \\
\hline $\begin{array}{c}k_{i} \text { values } \\
\left(\mathrm{L} \mathrm{mol}^{-1} \mathrm{~s}^{-1}\right)\end{array}$ & $\begin{array}{c}k_{17}=10^{9} \\
k_{-18}=3 \times 10^{9} \\
k_{19}=5 \times 10^{9} \\
k_{-20}=10^{10} \\
k_{21}=10^{8}\end{array}$ & $\begin{array}{c}\mathrm{k}_{17}=10^{10} \\
\mathrm{k}_{-18}=5 \times 10^{10} \\
\mathrm{k}_{19}=2.5 \times 10^{10} \\
\mathrm{k}_{-20}=7.5 \times 10^{10} \\
\mathrm{k}_{21}=10^{9}\end{array}$ & $\begin{array}{c}k_{17}=10^{9} \\
k_{-18}=3 \times 10^{9} \\
k_{29}=5 \times 10^{9} \\
k_{-30}=7.5 \times 10^{10} \\
k_{31}=10^{8}\end{array}$ & $\begin{array}{c}\mathrm{k}_{17}=10^{10} \\
\mathrm{k}_{-18}=5 \times 10^{10} \\
\mathrm{k}_{19}=2.5 \times 10^{10} \\
\mathrm{k}_{-20}=7.5 \times 10^{10} \\
\mathrm{k}_{21}=10^{9}\end{array}$ \\
\hline $\begin{array}{c}k_{\text {app,sim }} \\
\left(\mathrm{L} \mathrm{mol}^{-1} \mathrm{~s}^{-1}\right)\end{array}$ & $5.17 \times 10^{7}$ & $7.58 \times 10^{7}$ & $9.35 \times 10^{7}$ & $9.53 \times 10^{7}$ \\
\hline$t_{90}(s)$ & $1.47 \times 10^{-3}$ & $1.00 \times 10^{-3}$ & $3.00 \times 10^{-4}$ & $2.99 \times 10^{-4}$ \\
\hline $\begin{array}{c}\mathbf{k}_{\text {app, sim }} / \mathbf{k}_{\text {app,cal }} \\
(\%)\end{array}$ & 63.9 & 93.7 & 86.7 & 88.28 \\
\hline $\mathrm{R}^{2}$ & 0.991 & 1.000 & 0.999 & 0.999 \\
\hline
\end{tabular}

